Damian Bębnowski

(Uniwersytet Łódzki, Katedra Historii Myśli

Ekonomicznej i Historii Gospodarczej)

\title{
ANALIZA STATYSTYCZNA WYBRANYCH ASPEKTÓW HANDLU ZAGRANICZNEGO II RZECZYPOSPOLITEJ
}

\section{Uwagi wstępne: przedmiot badań i metodologia}

H

istoria gospodarcza jest nauką interdyscyplinarną, rozwijającą się na styku historii i ekonomii. Niejednokrotnie studia prowadzone w jej ramach wymagają sięgania do dorobku innych dyscyplin ${ }^{1}$. W badaniach historyczno-gospodarczych inspirujące wydaje się zatem korzystanie m.in. z metod ekonomicznych.

Opracowanie stanowi kontynuację oraz pogłębienie badań w zakresie bilansu handlu zagranicznego II Rzeczypospolitej. W 2014 roku opublikowałem tekst poświęcony tej problematyce ${ }^{2}$. Celem niniejszych rozważań jest próba statystycznego ujęcia wybranych aspektów zagranicznej wymiany handlowej Polski międzywojennej.

Dane zostały pozyskane z Małego Rocznika Statystycznego za lata 1930-1939 i obejmują okres 1922-1939 (por.: Aneks) ${ }^{3}$. Zawierają one następujące kategorie: import, eksport, saldo handlu zagranicznego (1922-1939); strukturę towarową importu i eksportu (1922-1934); import oraz eksport przez porty w Gdyni i Gdańsku (1927-1938); obrót handlu wewnętrznego (1924-1931). Wszystkie zmienne są wyrażone w milionach złotych (mln zł). Trudno pozyskać dokładne dane statystyczne dotyczące handlu zagranicznego Polski u progu niepodległości. Do 1 kwietnia 1919 roku nie prowadzono bowiem statystyk wymiany zagranicznej, a do 1 kwietnia 1920 roku opracowywane dane nie obejmowały transportów

\footnotetext{
${ }^{1}$ Literatura na temat historii gospodarczej w kontekście zachodzących w jej ramach związków między historią a ekonomią oraz innymi naukami jest bogata. Spośród polskich opracowań dotyczących teorii i metodologii historii gospodarczej na szczególną uwagę wciąż zasługuje klasyczna praca Witolda Kuli: W. Kula, Problemy i metody historii gospodarczej, PWN, Warszawa 1983.

2 D. Bębnowski, Bilans handlu zagranicznego II Rzeczypospolitej. Próby przezwyciężania kryzysów, [w:] Wiek XX wiekiem kryzysu? Kryzys człowieczeństwa, czyli ludobójstwa w minionym stuleciu, red. J. Gałuszka, Wydawnictwo KNHS UJ, Kraków 2014, s. 20-32.

${ }^{3}$ Maty Rocznik Statystyczny, 1930-1939.
} 
aprowizacyjnych i państwowych. W latach 1920-1921 uwzględniano wyłącznie ilościową statystykę przewożonych towarów. Ich wartość jest znana dopiero od 1922 roku. Na fakty te nakłada się dodatkowy problem przemytu (nie odnotowywanego w statystykach) oraz rozbieżności danych zawartych w źródłach, zwłaszcza w kontekście wartości przewożonych towarów. Stosowano bowiem różnorodne przeliczniki ich cen na złoto. $Z$ tego względu wszelkie dane statystyczne dla handlu zagranicznego II Rzeczypospolitej należy traktować jako orientacyjne ${ }^{4}$. Z kolei klamrą zamykającą - ze względu na późniejszy wybuch II wojny światowej-jest 31 lipca 1939 roku$^{5}$. Braki danych odpowiadają takowym występującym w Małym Roczniku Statystycznym. Pozostałe przypadki przedziałów czasowych zostaną omówione w odpowiednich miejscach w dalszej częściach rozważań ${ }^{6}$.

Badania zostały przeprowadzone $\mathrm{z}$ wykorzystaniem programu statystycznego $\mathrm{Gretl}^{7}$, a jego wyniki skonfrontowane $\mathrm{z}$ wybraną literaturą. Przedmiotem analizy były następujące zależności:

1) import a eksport Polski;

2) import a obrót handlu wewnętrznego w Polsce;

3) eksport a obrót handlu wewnętrznego w Polsce;

4) polski import globalny a import przez port w Gdyni;

5) polski import globalny a import przez port w Gdańsku;

6) polski eksport globalny a eksport przez port w Gdyni;

7) polski eksport globalny a eksport przez port w Gdańsku.

\footnotetext{
${ }^{4}$ Z. Landau, J. Tomaszewski, Gospodarka Polski międzywojennej 1918-1939, t. I: W dobie inflacji 1918-1923, Warszawa 1967, s. 341, przyp. 80. Co prawda, autorzy podają dane dotyczące polskiego bilansu handlowego za lata 1920-1921, jednak są one wyrażone w tysiącach ton. Ich uwzględnienie $\mathrm{w}$ analizie (opartej na danych w milionach złotych) byłoby błędem (por.: tamże, tabl. 88). Na problem szacunkowości danych w badaniach historyczno-gospodarczych zwrócił uwagę Jan Rutkowski w 1946 r. w teoretyczno-metodologicznym wstępie do swojej syntezy dziejów gospodarczych Polski (J. Rutkowski, Historia gospodarcza Polski, t. I: Czasy przedrozbiorowe, Księgarnia Akademicka, Poznań 1946, s. 9-10).

${ }^{5}$ Por.: Z. Landau, J. Tomaszewski, dz. cyt., t. IV: Lata interwencjonizmu państwowego 1936-1939, Książka i Wiedza, Warszawa 1989, s. 496, tabl. 85; 497-498.

${ }^{6}$ Jak słusznie podkreślił J. Rutkowski: (...) sprawa jednolitości chronologicznej [w badaniach historyczno-gospodarczych - przyp. D.B.] musi być bez porównania swobodniej traktowana niż to byłoby możliwe przy badaniach nad wspótczesnościa (J. Rutkowski, dz. cyt., s. 10).

${ }^{7}$ Program Gretl jest popularnym pakietem ekonometrycznym opracowanym przez Allina Cottrella z Uniwersytetu Wake Forest w Północnej Karolinie w Stanach Zjednoczonych. Program jest dostępny bezpłatnie - również w polskiej wersji językowej - dla wszystkich użytkowników na stronach internetowych: http://gretl.sourceforge.net/ oraz http://www.kufel.torun.pl/ (dostęp: 04.02.2016). Szerzej na temat wykorzystania programu w badaniach naukowych: T. Kufel, Ekonometria. Rozwiązywanie problemów z wykorzystaniem programu GRETL, WN PWN, Warszawa 2007.
} 
Analiza objęła również:

8) udział importu przez porty w Gdyni i Gdańsku w polskim imporcie globalnym;

9) udział eksportu przez porty w Gdyni i Gdańsku w polskim eksporcie globalnym;

10) strukturę towarową polskiego importu;

11) strukturę towarową polskiego eksportu.

W przypadku pkt. 1-7 skonstruowano proste modele ekonometryczne oparte na metodach, jakimi są: korelacja liniowa Pearsona i regresja liniowa. Celem pierwszej z nich jest zmierzenie relacji między dwiema zmiennymi oraz określenie siły i kierunku tej zależności. Druga metoda zakłada prezentację związku między zmiennymi za pomocą linii regresji. Linia ta jest prostą dopasowaną do punktów określających wyniki badania w taki sposób, aby odległość między punktami a prostą była jak najmniejsza (mówi się, że linia regresji jest wówczas najlepiej dopasowana do obserwacji i najdokładniej oddaje zależność między zmiennymi). Istnieje zatem wyraźny związek między korelacją a regresją. Należy jednak wyraźnie podkreślić, iż istnienie związku między zmiennymi nie musi oznaczać występowania zależności przyczynowej, tzn. związku deterministycznego (przyczynowo-skutkowego) odpowiadającego rzeczywistości ${ }^{8}$. Dla pkt. 8-11 wykorzystano podstawowe statystyki opisowe (średnią arytmetyczną i medianę) oraz skonstruowano odpowiednie wykresy i tabele 9 .

\section{Analiza}

\subsection{Import a eksport Polski}

Dane dotyczące polskiego importu i eksportu globalnego obejmują lata 1922-1939 i dotyczą handlu specjalnego. Uwzględniał on towary importowane dopuszczone do obrotu wewnętrznego oraz towary eksportowane, które zostały wyprodukowane lub uszlachetnione na polskim obszarze celnym. Handel specjalny nie dotyczył tranzytu, towarów na składach wolnocłowych oraz obrotu czasowego. Pod pojęciem polskiego obszaru celnego należy rozumieć terytorium państwa polskiego wraz z Wolnym Miastem Gdańsk ${ }^{10}$. Dane dotyczące importu i eksportu

${ }^{8}$ Por.: G. Koop, Wprowadzenie do ekonometrii, Oficyna a Wolters Kluwer Business, Warszawa 2014, s. 30-38, 44-49; J. Topolski, Metodologia historii, PWN, Warszawa 1973, s. 462-465.

${ }^{9}$ Stosowanie metod statystycznych w badaniach historyczno-gospodarczych powinno być dostosowane zarówno do przedmiotu badań, jak i materiału (zwłaszcza źródłowego), którym dysponuje uczony. Jak słusznie zauważył J. Rutkowski: Znacznie częściej jednakże [współczesna - przyp. D.B.] metoda statystyczna musi być modyfikowana ze względu na charakter źródel, do których historyk z konieczności jest ograniczony (J. Rutkowski, dz. cyt., s. 9).

${ }^{10}$ Maty Rocznik..., 1937, s. 151. 
nie obejmują złota, srebra i monet. Bilans dla lat 1922-1927 został przeliczony na złote na podstawie parytetu: $1 \mathrm{~kg}$ czystego złota $=5924,44 \mathrm{zł}$. Z kolei bilans dla 1922 roku objął również obrót czasowy. Dla lat 1923-1928 nie uwzględniono obrotu uszlachetniającego ${ }^{11}$.

Dane dla importu i eksportu można uznać za kompletne. Obejmują bowiem lata 1922-1939 (18 lat, $\mathrm{n}=18)$. Celem tej części badań jest udzielenie odpowiedzi na pytanie: jak kształtowały się relacje między polskim importem a eksportem we wskazanym okresie? Trudno jednoznacznie założyć, która zmienna mogła mieć większy wpływ na drugą, dlatego uzasadnione wydaje się zbadanie obustronnych relacji, mimo że korelacja liniowa Pearsona nie musi ukazywać przyczynowości. W obu sytuacjach hipoteza zerowa zakłada, że między zmiennymi nie zachodzi związek, zaś hipoteza alternatywna mówi, że ów związek istnieje. Taki sposób formułowania hipotez jest charakterystyczny dla badań statystycznych. Podstawy do odrzucenia hipotezy zerowej zaistnieją wówczas, gdy wartość bezwzględna współczynnika korelacji liniowej Pearsona przekroczy wartość krytyczną (obie wielkości można obliczyć w programie Gretl). W sytuacji odwrotnej takiej możliwości nie ma. Wówczas istnieją przesłanki, aby przyjąć hipotezę zerową ${ }^{12}$.

Jeżeli chodzi o relację import-eksport, to zmienną niezależną $X$ będzie import (wyrażony - podobnie jak pozostałe dane - w milionach złotych), podczas gdy zmienną zależną Y - eksport ${ }^{13}$. Obliczenia wykazały, że współczynnik korelacji liniowej Pearsona w tym przypadku wynosi 0,9167, zaś wartość krytyczna (przy dwustronnym 5\% obszarze krytycznym) jest równa 0,4683 dla $n=18$. Wartość bezwzględna współczynnika przekracza wartość krytyczną, są zatem podstawy do odrzucenia hipotezy zerowej. Należy więc stwierdzić, iż między zmiennymi X i Y istnieje związek. Jest on nawet bardzo silny, wartość współczynnika przekracza bowiem 0,6 i jest zbliżona do 1 . Co więcej, ma ona znak dodatni, zmienne wzrastają więc w tym samym kierunku - w latach 1922-1939 wzrost importu sprzyjał wzrostowi eksportu.

W przypadku konfiguracji eksport-import (zmienna niezależna $\mathrm{X}$ - eksport, zmienna zależna $\mathrm{Y}$ - import) wynik jest identyczny. Zmieni się jednak sposób jego interpretacji: w omawianym okresie wzrost eksportu wpływał na wzrost importu.

Powyższa sytuacja nie powinna dziwić. Wynika ona $\mathrm{z}$ faktu, iż korelacja liniowa Pearsona mierzy relację obustronną zmiennych. Ponadto nie musi wskazywać związków przyczynowo-skutkowych między nimi.

Zobrazowaniu pierwszej konfiguracji (X - import, Y - eksport) służy wykres 1 wygenerowany przez program Gretl.

${ }^{11}$ Tamże, 1930-1939.

${ }^{12}$ G. Koop, dz. cyt., s. 94-95.

${ }^{13} \mathrm{~W}$ badaniach statystycznych przyjmuje się, że zmienna niezależna $\mathrm{X}$ wpływa na zmienną zależną Y. Pierwsza z nich jest zatem zmienną objaśniającą, druga zaś - objaśnianą (M. Sobczyk, Statystyka, WN PWN, Warszawa 2007, s. 256). 
Wykres 1. Eksport względem importu (opracowanie własne)

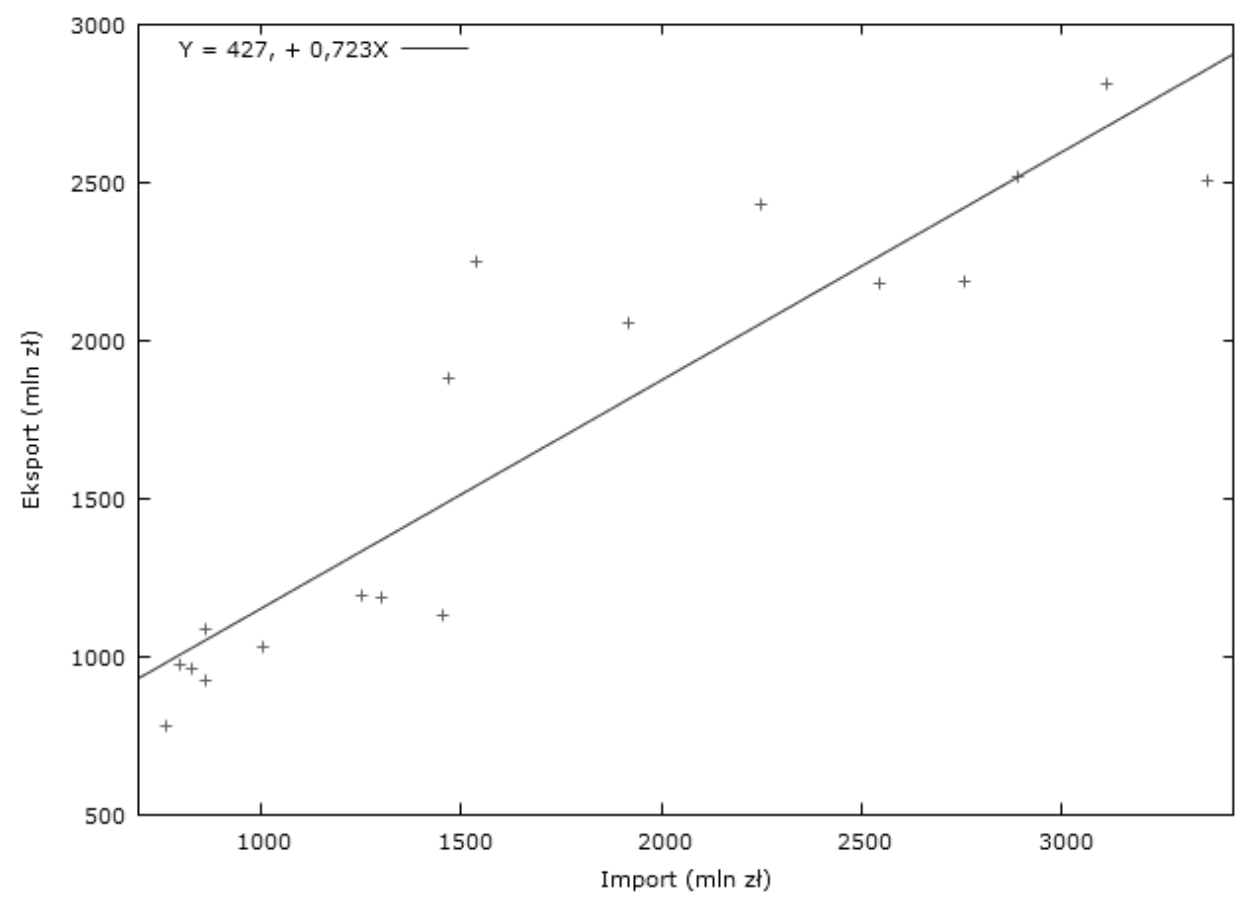

Z wykresu wynika, że między zmiennymi X i Y istnieje związek prostoliniowy o charakterze dodatnim. W latach 1922-1939 wzrostowi importu odpowiadał wzrost eksportu. Widoczne na wykresie równanie regresji należy interpretować w sposób następujący: jeżeli X (import) wzrósł o jednostkę ( $1 \mathrm{mln}$ zł), to efekt zmiany Y (eksportu) wyniósł 0,723 mln zł (wzrost wartości o $0,723 \mathrm{mln}$ zł). Obliczenie w programie Gretl współczynnika determinacji $\mathrm{R}^{2}$ pozwala zaś ocenić stopień dopasowania modelu do danych. Innymi słowy, określa skuteczność oszacowania wpływu zmiennej $\mathrm{X}$ na zmienną $\mathrm{Y}^{14}$. W omawianym przypadku $\mathrm{R}^{2}=0,840307$, co oznacza, że w $0,84 \%$ udało się oszacować wpływ importu na eksport.

Odwrotną konfigurację zmiennych przedstawia wykres 2 (X - eksport, $\mathrm{Y}$ - import).

Porównanie obu wykresów pozwala na wyciągnięcie kilku zasadniczych wniosków. Po pierwsze, należy zwrócić uwagę, że chmury punktów na obu wykresach stanowią względem siebie swoiste odbicie lustrzane. Wynika to z przyjęcia kolejno konfiguracji: import-eksport oraz eksport-import. Po drugie, potwierdzają się wcześniejsze konkluzje dotyczące istnienia dodatniego związku między zmiennymi (w latach 1922-1939 wzrost importu sprzyjał wzrostowi eksportu i odwrotnie

\footnotetext{
${ }^{14}$ G. Koop, $d z$. cyt., s. 50-52.
} 
Wykres 2. Import względem eksportu (opracowanie własne)

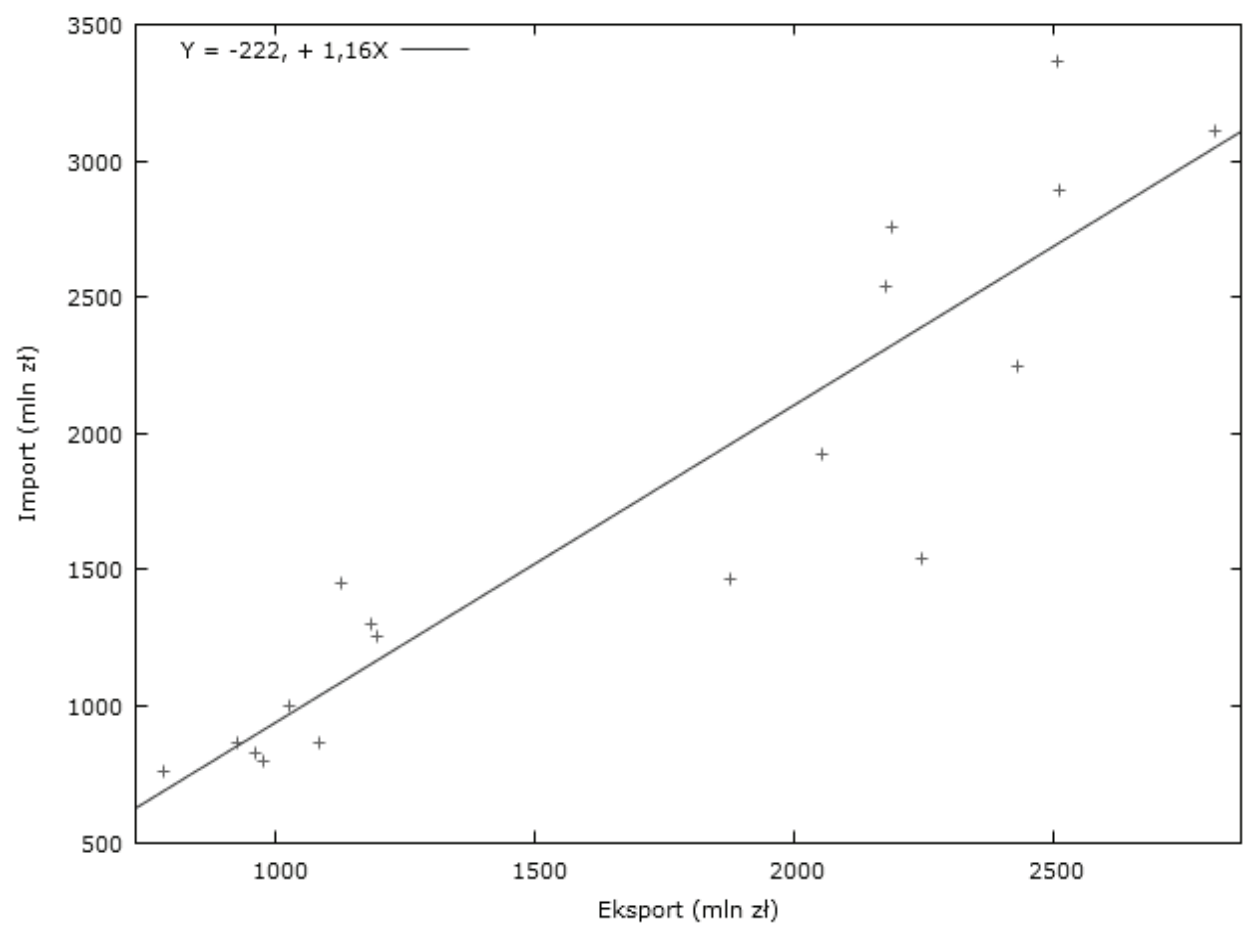

- wzrost eksportu wpływał na wzrost importu). Po trzecie, różnicę między specyfiką owych relacji można uchwycić dzięki interpretacji równań regresji, wygenerowanych przez program Gretl. Z równania pierwszego (wykres 1) wynika, że w sytuacji, gdy import wzrósł o $1 \mathrm{mln}$ zł, to efekt zmiany eksportu wyniósł 0,723 $\mathrm{mln}$ zł. Interpretacja drugiego równania (wykres 2) brzmi natomiast następująco: jeżeli eksport wzrósł o $1 \mathrm{mln} \mathrm{zł}$, to import wzrósł o $1,16 \mathrm{mln}$ zł. W kontekście obustronnych relacji import-eksport może to oznaczać, że w większym stopniu eksport wpływał na import niż odwrotnie. Różnica nie była jednak zbyt duża $\left(0,437 \mathrm{mln}\right.$ zł). Po czwarte, warto porównać współczynniki determinacji $\mathrm{R}^{2}$. Okazuje się, że zarówno dla pierwszej (wykres 1), jak i drugiej sytuacji (wykres 2) wynosi on 0,840307 , to znaczy, że w $84 \%$ udało się oszacować wpływ zmiennej $\mathrm{X}$ na zmienną Y (niezależnie od konfiguracji: import-eksport czy eksport-import). Po piąte, wykazane niuanse wynikają z kwestii metodologicznych. Jak już zostało kilkakrotnie wspomniane, korelacja liniowa Pearsona i regresja liniowa nie muszą określać związków przyczynowo-skutkowych. Trudno zatem jednoznacznie rozstrzygnąć, która zmienna determinowała drugą, o ile w ogóle zachodziła między nimi przyczynowość. Analiza równań regresji pozwala jednak zakładać większy wpływ wywozu na przywóz. 
Powyższe wątpliwości uzasadniają wykorzystanie innej metody, która przybliży relacje między polskim importem a eksportem w latach 1922-1939. Może nią być skonstruowanie wielokrotnego wykresu liniowego szeregów czasowych dotyczących przywozu i wywozu.

Wykres 3 pokazuje, że w ciągu 18 lat (1922-1939) 10-krotnie odnotowano dodatni bilans handlowy. Ta pozytywna cecha gospodarki objęła jednak względną połowę czasu istnienia II Rzeczypospolitej. Głębsza analiza wykresu pozwala wyodrębnić lata z saldem dodatnim i ujemnym. Największa częstotliwość zmian przypadła na lata dwudzieste XX wieku. Mniej dynamiczne pod tym względem były lata trzydzieste. Bilans dodatni objął okres 1930-1936 oraz pierwszą połowę 1939 roku (dane dotyczą okresu od 1 stycznia do 31 lipca 1939 r.). Lata $1937-1938$ wykazały bilans ujemny.

Wykres 3. Polski import a eksport w latach 1922-1939 (opracowanie własne)

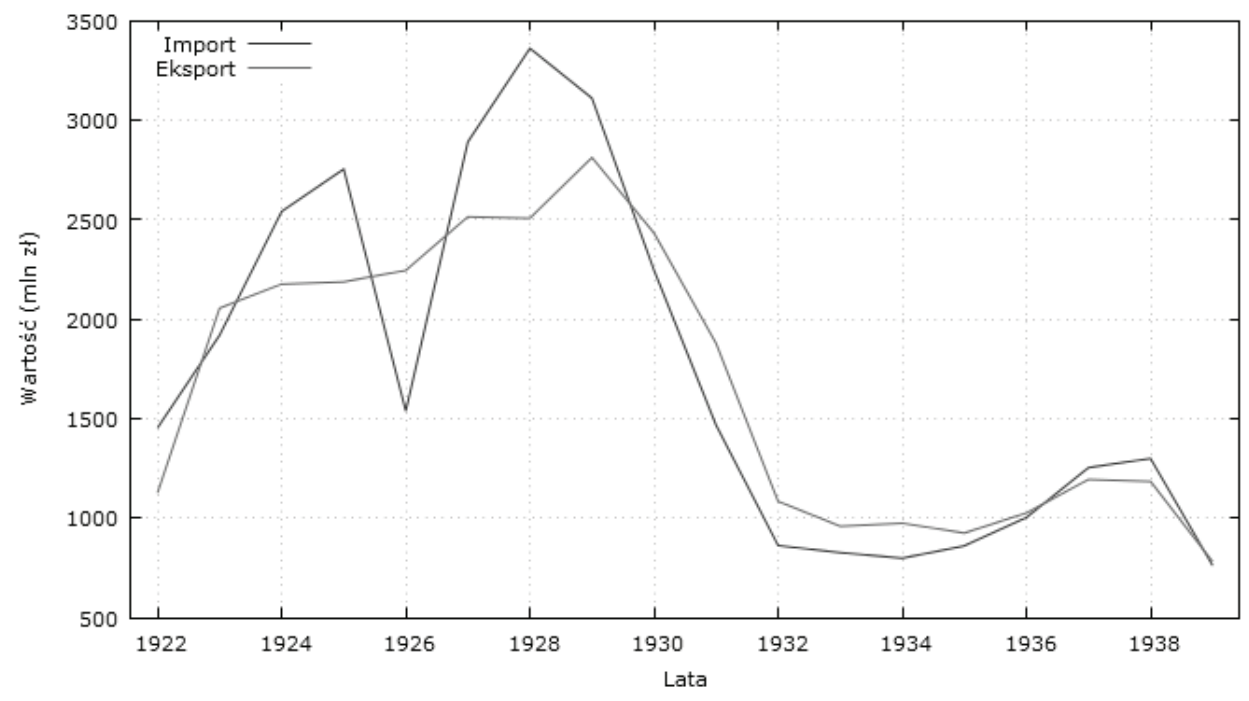

\subsection{Import a obrót handlu wewnętrznego w Polsce}

Dane dla importu (eksportu) obejmują lata 1922-1939, zaś dla obrotu wewnętrznego - 1924-1931. Obserwacje wspólne dla importu (eksportu) i obrotu krajowej wymiany dotyczą okresu 1924-1931. Zatem liczba obserwacji wynosi $8(\mathrm{n}=8)$.

Pytanie badawcze brzmi: jak kształtowały się relacje między importem a obrotem handlu wewnętrznego w Polsce w latach 1924-1931? Podobna analiza, dotycząca eksportu, zostanie przeprowadzona w punkcie 2.3. Tak jak w poprzednim badaniu (pkt. 2.1.), trudno jednoznacznie rozstrzygnąć, która ze zmiennych wywierała większy wpływ na drugą. 
Niezależnie od przyjętych konfiguracji zmiennych (X - import, $\mathrm{Y}$ - obrót handlu wewnętrznego lub X - obrót handlu wewnętrznego, Y - import), hipoteza zerowa zakłada brak związku między zmiennymi, zaś hipoteza alternatywna taki związek dopuszcza.

Współczynnik korelacji między zmiennymi X i Y wynosi 0,8689. Wartość krytyczna (przy dwustronnym 5\% obszarze krytycznym) jest równa 0,7067 dla n $=8$. Istnieją przesłanki, aby odrzucić hipotezę zerową. Wartość współczynnika jest dodatnia, zatem zmienne wzrastają w tym samym kierunku. W przypadku pierwszej konfiguracji wzrost importu powodował wzrost obrotu handlu wewnętrznego w Polsce w latach 1924-1931. W przypadku drugiej - wzrost obrotu wymiany krajowej sprzyjał wzrostowi przywozu. W obu przypadkach związek jest silny (wartość współczynnika przekracza 0,6).

Obie konfiguracje zmiennych obrazują wykresy 4 i 5.

Wykres 4. Obrót handlu wewnętrznego względem importu (opracowanie własne)

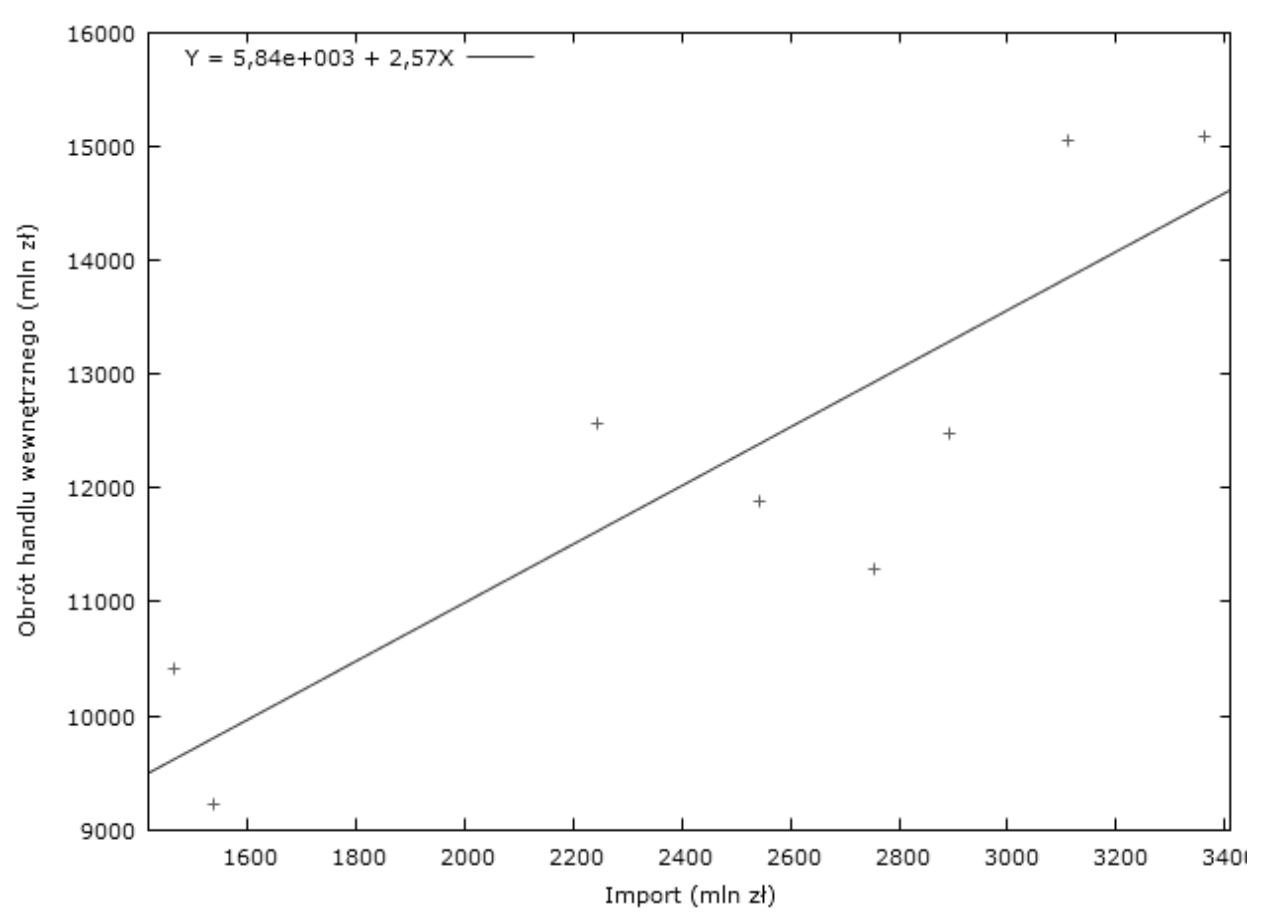

Z obu wykresów wynika, że między zmiennymi X i Y istnieje związek prostoliniowy o charakterze dodatnim. Pozostaje kwestia interpretacji poszczególnych konfiguracji. Wykres 4 wskazuje, że w latach 1924-1931 wzrostowi importu 
odpowiadał wzrost obrotu handlu wewnętrznego. Widoczne równanie regresji sugeruje zaś prawidłowość: jeżeli import wzrósł o $1 \mathrm{mln}$ zł, to obrót handlu wewnętrznego wzrósł o 2,57 mln zł. Wykres 5 z kolei wskazuje inną zależność: w omawianym okresie wzrost obrotu krajowej wymiany handlowej sprzyjał wzrostowi przywozu. Równanie regresji precyzuje tę zależność. Jeżeli obrót wzrósł o $1 \mathrm{mln}$ zł, to wartość importu była większa o $0,293 \mathrm{mln}$ zł. W obu przypadkach $\mathrm{R}^{2}=0,755$, co oznacza, że w 75,5\% udało się oszacować wpływ jednej zmiennej na drugą, niezależnie od przyjętej konfiguracji. Można zatem przypuszczać, iż w latach 1924-1931 import w większym stopniu wpływał na obrót handlu wewnętrznego niż odwrotnie.

Wykres 5. Import względem obrotu handlu wewnętrznego (opracowanie własne)

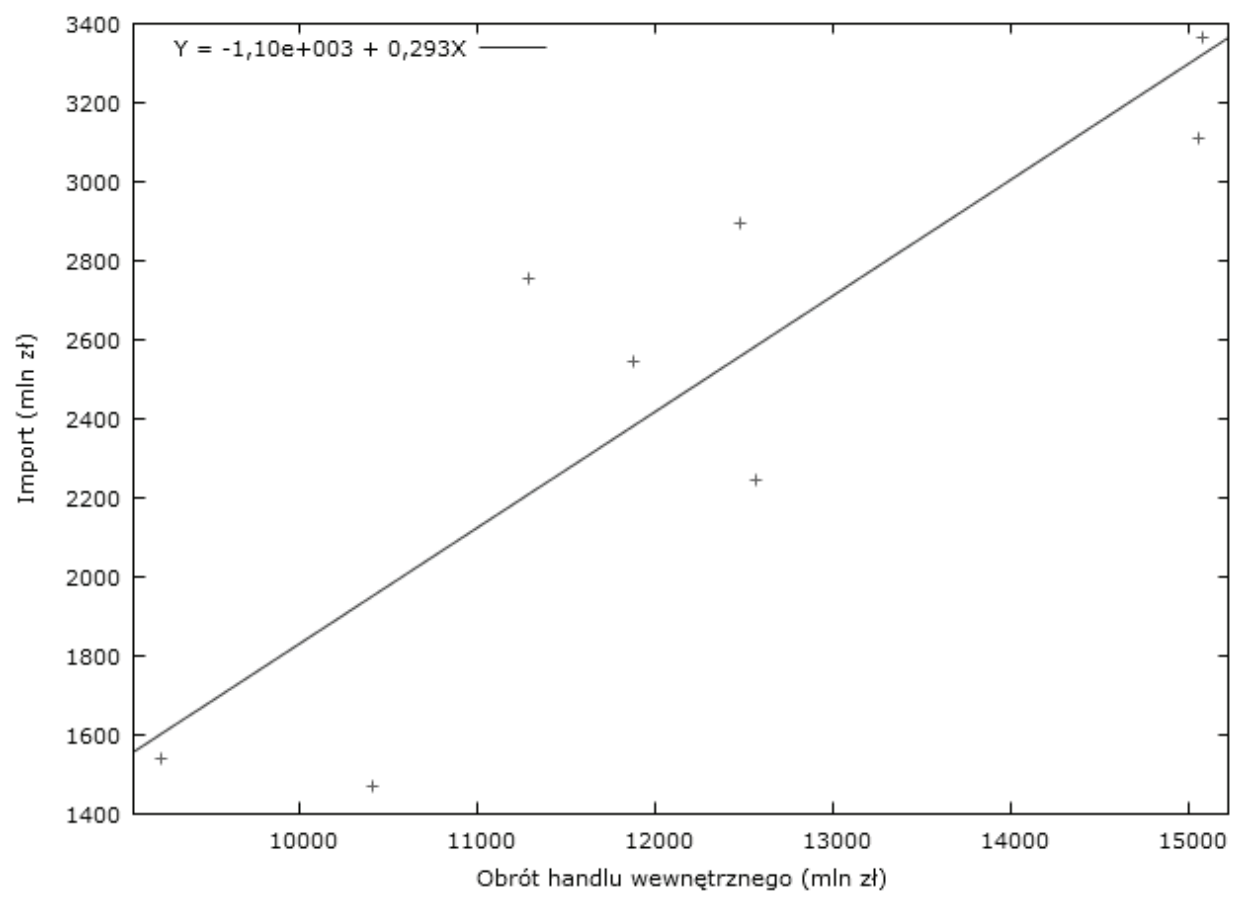

\subsection{Eksport a obrót handlu wewnętrznego w Polsce}

Tak jak poprzednio, dane dla eksportu obejmują lata 1922-1939, zaś dla obrotu wewnętrznego - okres 1924-1931. Zatem liczba wspólnych obserwacji wynosi $8(\mathrm{n}=8)$. Ponownie, celem niniejszego badania będzie udzielenie odpowiedzi na następujące pytanie: jak kształtowały się relacje między eksportem a obrotem 
handlu wewnętrznego w Polsce w latach 1924-1931? Jak zasygnalizowano wcześniej, wskutek braku możliwości rozstrzygnięcia, która zmienna w większym stopniu wpływa na drugą, należy wziąć pod uwagę dwie konfiguracje: $\mathrm{X}$ - eksport, Y - obrót handlu wewnętrznego oraz X - obrót handlu wewnętrznego, $\mathrm{Y}$ - eksport. W obu przypadkach hipoteza zerowa wyklucza związek między zmiennymi, zaś hipoteza alternatywna zakłada istnienie owego związku.

Niezależnie od przyjętej konfiguracji współczynnik korelacji liniowej Pearsona między zmiennymi X i Y wynosi 0,7865 . Wartość krytyczna (przy dwustronnym 5\% obszarze krytycznym) jest równa 0,7067 dla $n=8$. Istnieją podstawy do odrzucenia hipotezy zerowej. Między zmiennymi istnieje związek. Jest on silny, ponieważ wartość współczynnika przekracza 0,6 . Wartość ta jest dodatnia, zatem zmienne wzrastają w tym samym kierunku. Jeżeli chodzi o pierwszą konfigurację, wzrost eksportu generował wzrost obrotu wymiany krajowej. W drugim przypadku wzrost obrotu handlu wewnętrznego sprzyjał wzrostowi wywozu.

Powyższe wnioski obrazują wykresy 6 i 7.

Wykres 6. Obrót handlu wewnętrznego względem eksportu (opracowanie własne)

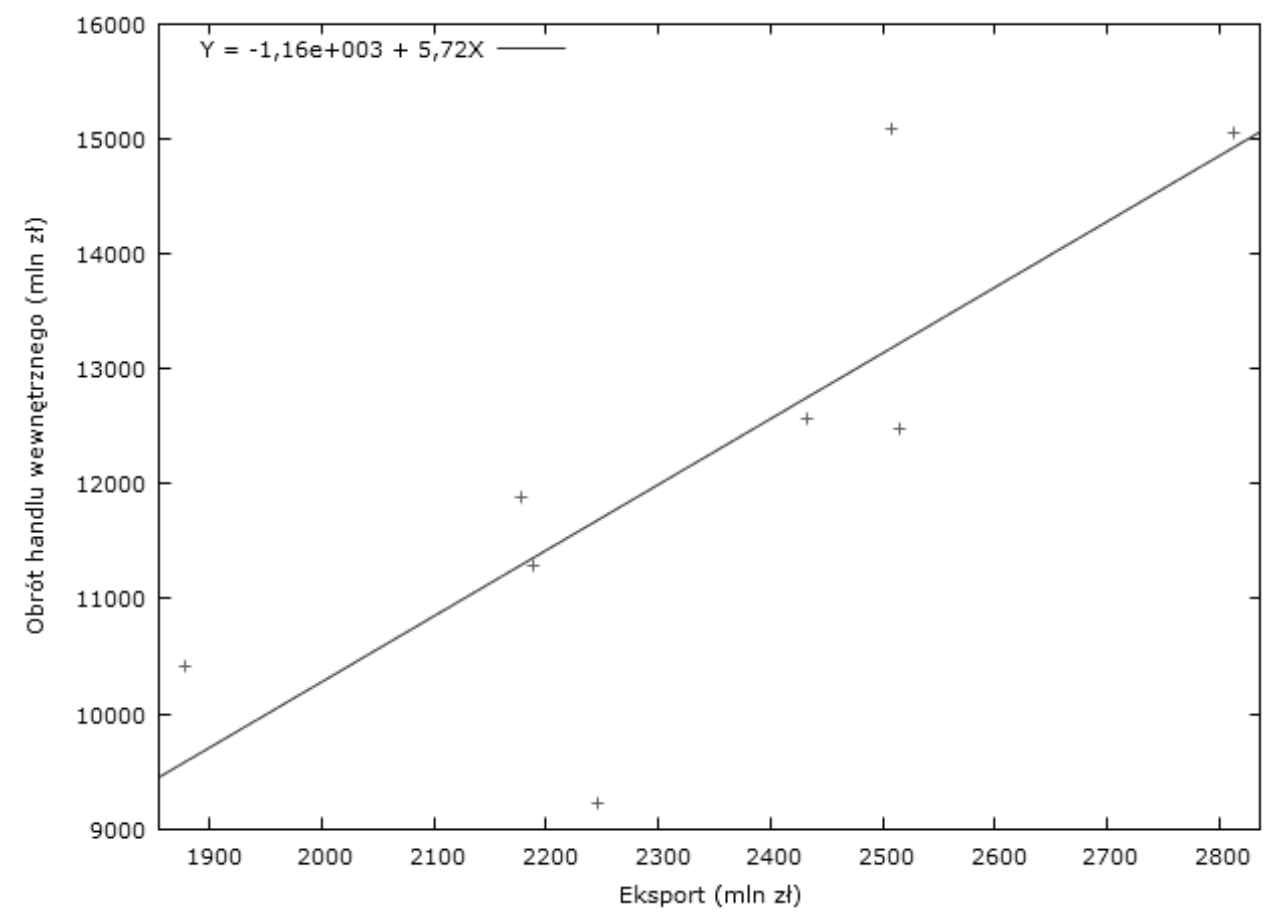


Wykres 7. Eksport względem obrotu handlu wewnętrznego (opracowanie własne)

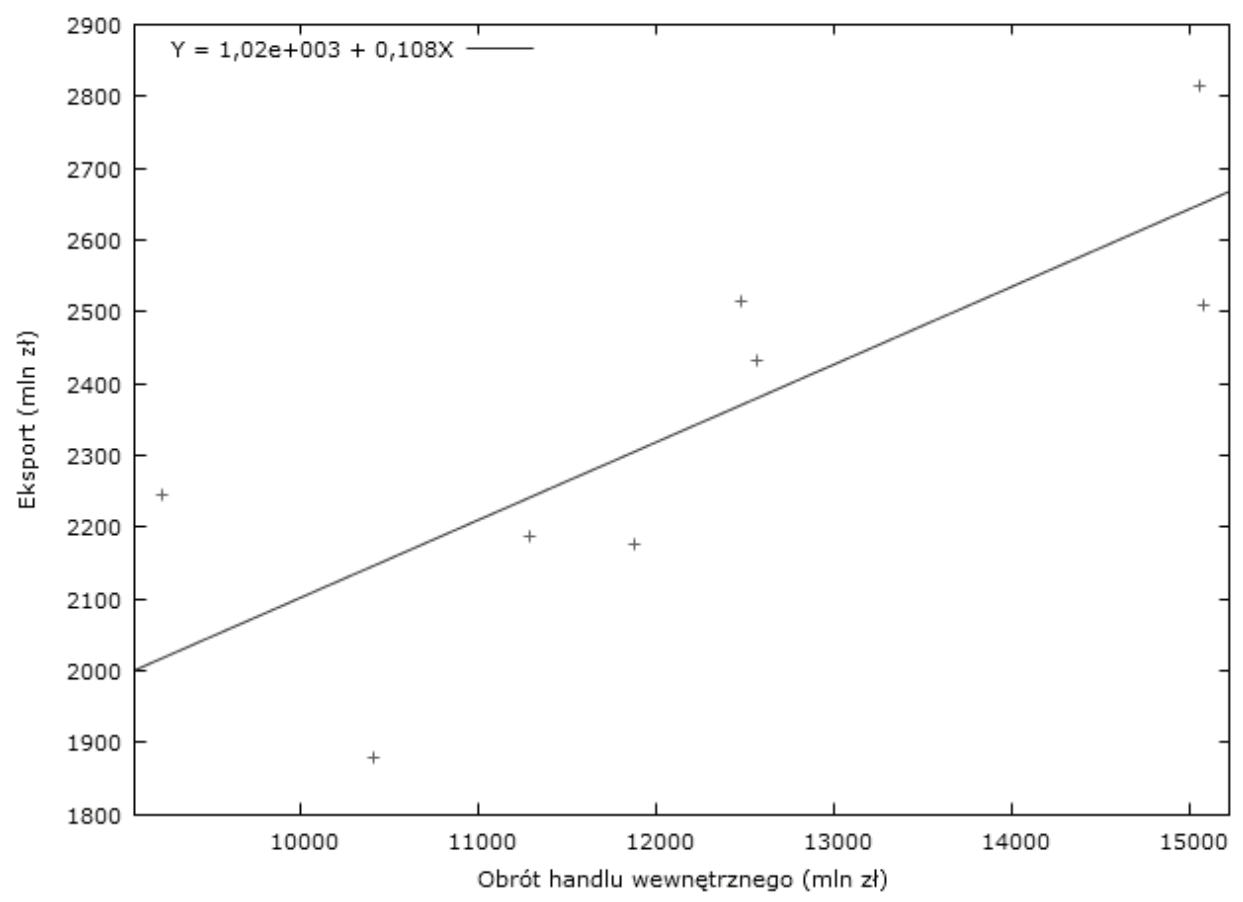

Między zmiennymi X a Y istnieje związek prostoliniowy o charakterze dodatnim. Równanie regresji z wykresu 6 - ukazującego wpływ eksportu na obrót wymiany wewnętrznej - należy interpretować w sposób następujący: jeżeli wartość wywozu wzrosła o $1 \mathrm{mln}$ zł, to wartość obrotu handlu krajowego wzrosła o 5,72 mln zł. Z kolei równanie regresji znajdujące się na wykresie 7 - przedstawiającym wpływ obrotu wewnętrznego Polski na wywóz - sugeruje, że wzrost obrotu handlu wewnętrznego o $1 \mathrm{mln}$ zł generował wzrost eksportu o 0,108 mln zł. Współczynnik determinacji $\mathrm{R}^{2}$ wynosi 0,618578 , co oznacza, że w $61,9 \%$ udało się oszacować wpływ jednej zmiennej na drugą. Wynika $z$ tego, iż w latach 1924-1931 wywóz $w$ większym stopniu wpływal na obrót handlu wewnętrznego niż odwrotnie.

Należy przypomnieć, że wzrost przywozu o $1 \mathrm{mln}$ zł wpływał na wzrost obrotu wymiany wewnętrznej Polski o $2,57 \mathrm{mln}$ zł (por.: pkt. 2.2.). Można zatem stwierdzić, iż eksport w większym stopniu niż import generował wzrost obrotu handlu wewnętrznego. Innymi słowy, im więcej II Rzeczpospolita eksportowała, tym bardziej rozwijal się handel krajowy. 


\subsection{Polski import globalny a import przez port w Gdyni}

Kolejne aspekty handlu zagranicznego Polski międzywojennej (pkt. 2.4.-2.7.) będą łatwiejsze do analizy. W ich przypadku prościej bowiem wskazać potencjalną zmienną niezależną determinującą ewentualne przemiany $\mathrm{w}$ zakresie zmiennej zależnej. Dotyczą one relacji między importem i eksportem globalnym a importem i eksportem przez najważniejsze polskie porty, tj. Gdynię i Gdańsk. Z kolei punkty 2.10.-2.11. będą poświęcone udziałowi importu i eksportu przez Gdynię i Gdańsk w imporcie i eksporcie globalnym. Mimo iż w okresie międzywojennym Gdańsk nie należał do Polski (miał status wolnego miasta pozostającego pod zarządem Wysokiego Komisarza Ligi Narodów), to wraz z Gdynią odgrywał zasadniczą rolę dla polskiej gospodarki. Były to bowiem porty pełnomorskie umożliwiające prowadzenie handlu dalekosiężnego ${ }^{15}$.

${ }^{15}$ Wolne Miasto Gdańsk formalnie powołano do istnienia 15 listopada $1920 \mathrm{r}$. Na mocy traktatu wersalskiego z 28 czerwca 1919 r. Gdańsk został włączony do polskiego obszaru celnego. Oznaczało to, że statki Rzeczypospolitej w porcie gdańskim były traktowane na równi ze statkami Wolnego Miasta. Polska uzyskała również prawo m.in. do korzystania z portu gdańskiego, kontroli Wisły, zarządu głównych sieci kolejowych i systemu łączności (poczty, telegrafu, telefonu). Te ogólne kwestie precyzyjniej regulowała paryska konwencja polsko-gdańska z 9 listopada 1920 r. Państwo polskie uzyskało m.in. prawo reprezentowania interesów miasta na arenie międzynarodowej przy jednoczesnym obowiązku zasięgania opinii władz Gdańska przed zawarciem umowy międzynarodowej istotnej dla miasta. Choć potwierdzono włączenie Wolnego Miasta do polskiego obszaru celnego, to urzędy celne powoływały gdańskie władze, lecz pod kontrolą polskich inspektorów. $\mathrm{W}$ administracji ceł język polski i polska waluta zostały równouprawnione z językiem niemieckim i gdańską walutą. Potwierdzono prawo Polski do korzystania z portu, choć oddano go pod zarząd polsko-gdańskiej rady portowej z wybieralnym prezydentem na czele. Państwo polskie przejęło zaś zarząd nad kolejami na terenie Wolnego Miasta. Oficjalnym reprezentantem Polski na tym obszarze był z kolei Komisarz Generalny Rzeczypospolitej Polskiej. Konwencja warszawska z 24 października $1921 \mathrm{r}$. dotyczyła m.in. kwestii celnych, pocztowych i telegraficznych. Co więcej, w $1921 \mathrm{r}$. aliancka komisja dla podziału mienia poniemieckiego w Gdańsku przyznała Rzeczypospolitej gdańskie zbiorniki naftowe, a także 50\% stoczni i warsztatów kolejowych (K. Piwarski, Dzieje Gdańska w zarysie, Wydawnictwo Adam Marszałek, Gdańsk 1997, s. 211-216; M. Kałuski, Polskie dzieje Gdańska do 1945 roku (Zbiór szkiców), Wydawnictwo Diecezji Pelplińskiej Bernardinum, Pelplin 2004, s. 139-141). Szerzej na temat gdańskiej waluty (marki niemieckiej i guldenu), poziomu cen w Wolnym Mieście oraz polsko-gdańskich przepisów granicznych, dewizowych, celnych i pocztowych: W. Morawski, Dzieje gospodarcze Polski, Wydawnictwo Difin, Warszawa 2010, s. 192-194.

Decyzję o budowie miasta i portu w Gdyni podjęto w 1920 r. Prace rozpoczęły się w roku następnym. Główną przyczyną tej wielkiej inwestycji były skomplikowane stosunki z Wolnym Miastem Gdańsk oraz potrzeba posiadania przez państwo polskie pełnomorskiego portu handlowego i wojennego. W ciągu kolejnych lat niewielka wioska rybacka przekształciła się w duże miasto z nowoczesnym portem. Szczególną rolę w tym zakresie odegrała polityka ministra przemysłu i handlu, Eugeniusza Kwiatkowskiego. W latach 1926-1933 wybudowano również magistralę węglową - linię kolejową łączącą Górny Śląsk z Gdynią (Dzieje Gdyni, red. R. Wapiński, Zakład Narodowy im. Ossolińskich, Wrocław 1980; M. Graban, Gdynia wobec przeobrażeń cywilizacyjnych XX i XXI wieku. Ewolucja czynników rozwoju miasta, Wyższa Szkoła Komunikacji Społecznej w Gdyni, Gdynia 2012, s. 75-115). 
Dane dla importu przez port w Gdyni obejmują lata 1927-1938. Zatem liczba wspólnych obserwacji z importem globalnym (który wraz z eksportem obejmuje lata 1922-1939) wynosi $12(\mathrm{n}=12)$. Pytanie badawcze brzmi: czy wzrost polskiego importu globalnego sprzyjał wzrostowi importu przez port w Gdyni w latach 1927-1938? Niech zmienną niezależną X będzie import globalny, a zmienną zależną Y - import przez Gdynię. Tak jak dotychczas, hipoteza zerowa zakłada, że między zmiennymi nie występuje związek, zaś hipoteza alternatywna głosi, że taki związek istnieje.

Współczynnik korelacji liniowej jest równy -0,6406. Wartość krytyczna (przy dwustronnym 5\% obszarze krytycznym) wynosi 0,5760 dla $n=12$. Wartość bezwzględna współczynnika przekracza wartość krytyczną, co pozwala na odrzucenie hipotezy zerowej i sformułowanie wniosku, iż między zmiennymi występuje związek. Wartość współczynnika jest jednak ujemna, zatem zmienne wzrastają w przeciwnych kierunkach - wzrost importu globalnego powodowal spadek importu przez port w Gdyni. Związek jest silny, gdyż wspomniana wartość przekracza 0,6 , choć tylko w niewielkim stopniu.

Wykres 8. Import przez port w Gdyni względem importu globalnego (opracowanie własne)

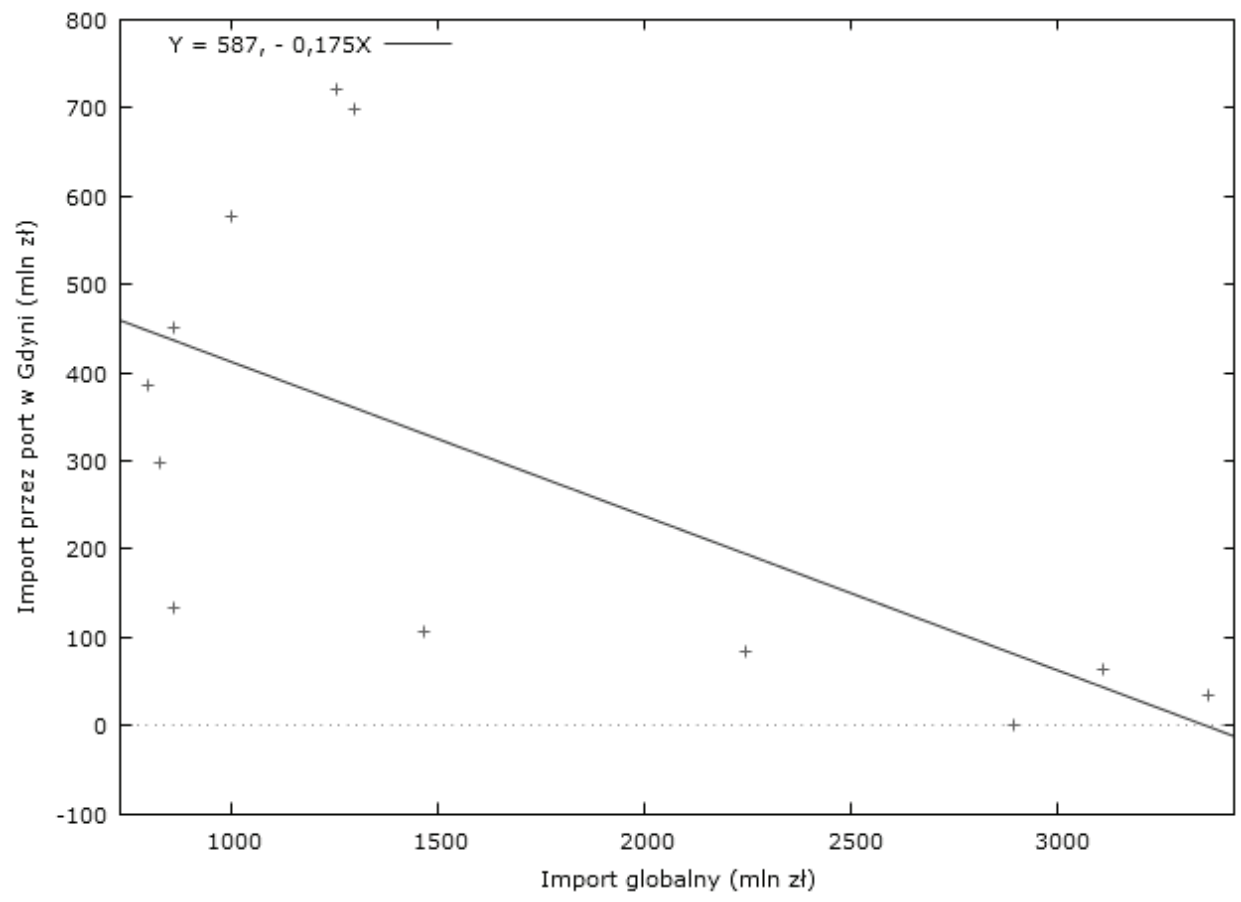


Układ punktów na wykresie 8 ma kształt zakrzywionej linii. Między zmiennymi X i Y istnieje związek o charakterze ujemnym. W latach 1927-1938 wzrostowi importu globalnego odpowiadał spadek przywozu przez port w Gdyni. Interpretacja równania regresji jest $\mathrm{w}$ tym przypadku następująca: jeżeli X (import globalny) wzrósł o jednostkę ( $1 \mathrm{mln}$ zł), to efekt zmiany Y (import przez port w Gdyni) wyniósł -0,175 mln zł (spadek wartości o 0,175 mln zł). Współczynnik determinacji $\mathrm{R}^{2}$ wynosi 0,410307 . W $41 \%$ udało się oszacować wpływ przywozu globalnego na import gdyński. Mimo to - w kontekście badań ekonometrycznych - wynik ten można uznać za zadowalający.

Powyższe konkluzje są interesujące $\mathrm{z}$ tego względu, iż znając znaczenie portu gdyńskiego dla polskiej gospodarki międzywojennej, należałoby się spodziewać wzrostu przywozu przez Gdynię względem wzrostu importu globalnego. Nie należy jednak przedwcześnie formułować jednoznacznych wniosków. Kolejne badania pogłębią analizę i naświetlą specyfikę omawianych aspektów polskiego handlu zagranicznego.

\subsection{Polski import globalny a import przez port w Gdańsku}

Podobnie jak w poprzednim przypadku, dane dla importu przez Gdańsk również obejmują lata 1927-1938. Zatem liczba wspólnych obserwacji wynosi $12(\mathrm{n}=12)$. Pytanie badawcze jest następujące: czy wzrost polskiego importu globalnego sprzyjał wzrostowi importu przez port w Gdańsku w latach 1927-1938? Zmienną niezależną $X$ jest import globalny, podczas gdy zmienną zależną $Y$ - import gdański. Hipoteza zerowa zakłada brak związku między zmiennymi, hipoteza alternatywna zaś taki związek dopuszcza.

Współczynnik korelacji liniowej Pearsona jest równy 0,9797. Wartość krytyczna (przy dwustronnym 5\% obszarze krytycznym) wynosi zaś 0,5760 dla $\mathrm{n}=12$. Istnieją podstawy do odrzucenia hipotezy zerowej, zatem między zmiennymi X i Y występuje związek. Wartość współczynnika jest dodatnia, więc zmienne wzrastają w tym samym kierunku - w latach 1927-1938 wzrost importu globalnego sprzyjał wzrostowi importu przez Gdańsk. Ta sama wartość przekracza 0,6 i jest zbliżona do 1 . Związek jest zatem bardzo silny.

Wykres 9 pokazuje dodatni związek między zmiennymi. W omawianym okresie wzrost polskiego importu globalnego wpływał na wzrost importu gdańskiego. Co więcej, wzrost tego pierwszego o $1 \mathrm{mln}$ zł powodował wzrost przywozu przez Gdańsk o 0,315 mln zł. W 96\% udało się oszacować wpływ importu globalnego na import przez Wolne Miasto $\left(\mathrm{R}^{2}=0,959729\right)$.

Badania dotyczące importu przez Gdynię i Gdańsk względem importu globalnego (pkt. 2.4.-2.5.) dostarczają interesującej konkluzji. Wynika z nich bowiem, iż im więcej Polska importowała w latach 1927-1938, tym więcej towarów wwożono przez Gdańsk, a mniej przez Gdynię. 
Wykres 9. Import przez port w Gdańsku względem importu globalnego (opracowanie własne)

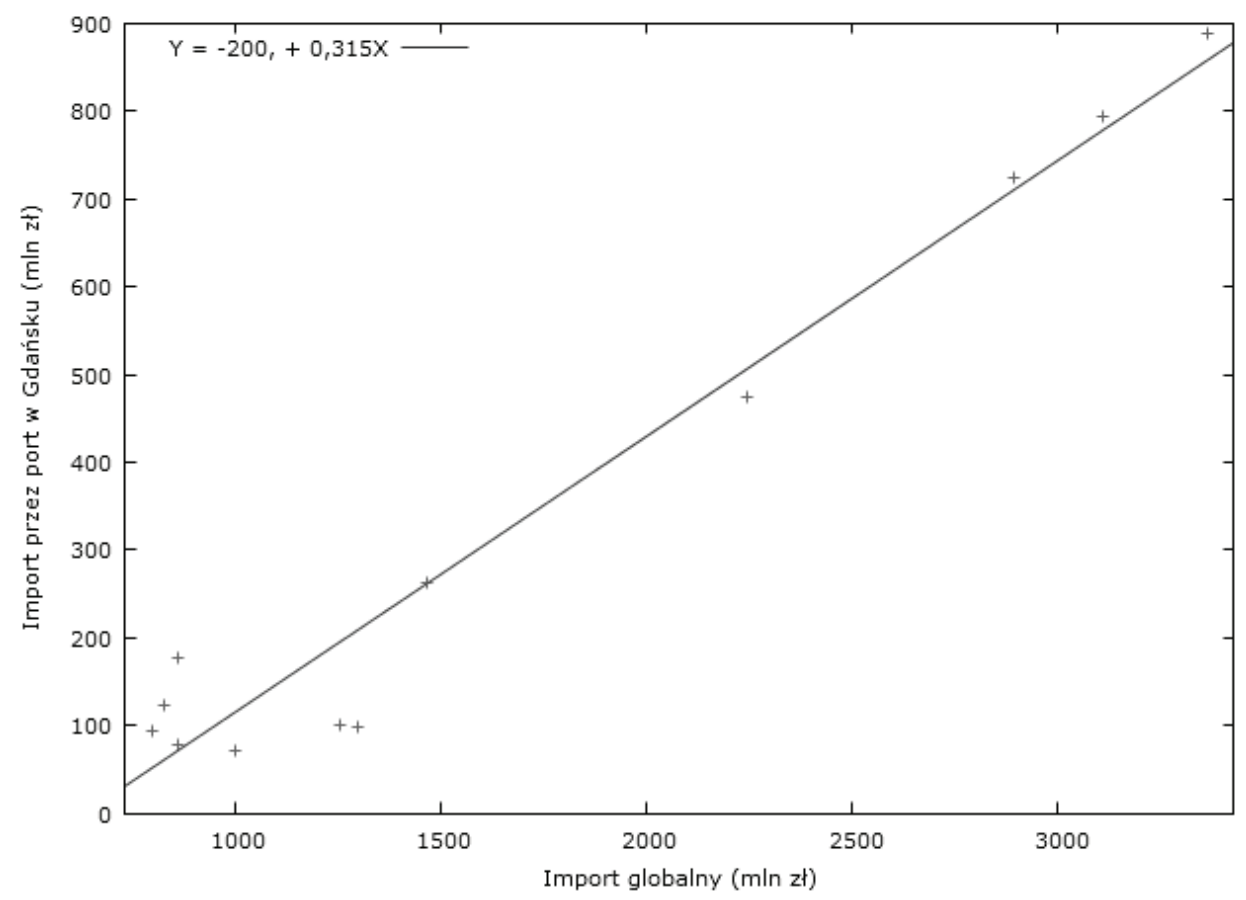

\subsection{Polski eksport globalny a eksport przez port w Gdyni}

Kolejne dwa badania (pkt. 2.6.-2.7.) dotyczyć będą relacji między eksportem globalnym a eksportem przez Gdynię i Gdańsk. Podobnie jak wcześniej, dane dotyczą tych samych przedziałów lat, zatem wspólne obserwacje obejmują okres 1927-1938, czyli 12 lat $(\mathrm{n}=12)$.

Zmienną niezależną $\mathrm{X}$ niech będzie eksport globalny, a zmienną zależną Y - eksport przez Gdynię. Umożliwi to udzielenie odpowiedzi na pytanie, czy wzrost polskiego eksportu globalnego sprzyjał wzrostowi eksportu przez port w Gdyni w latach 1927-1938? Brak tego typu związku zakłada hipoteza zerowa, podczas gdy hipoteza alternatywna tę relację dopuszcza.

Obliczony współczynnik korelacji liniowej wyniósł -0,7703. Dla $\mathrm{n}=12$ wartość krytyczna (przy dwustronnym 5\% obszarze krytycznym) jest zaś równa 0,5760. Oznacza to, że można odrzucić hipotezę zerową. Wartość bezwzględna współczynnika jest bowiem większa niż wartość krytyczna. Zatem, między zmiennymi X i Y istnieje związek. Ma on jednak charakter ujemny - wzrostowi eksportu globalnego towarzyszył spadek eksportu przez Gdynię. Korelacja jest silna, ponieważ współczynnik przekracza -0,6. 
Wykres 10. Eksport przez port w Gdyni względem eksportu globalnego (opracowanie własne)

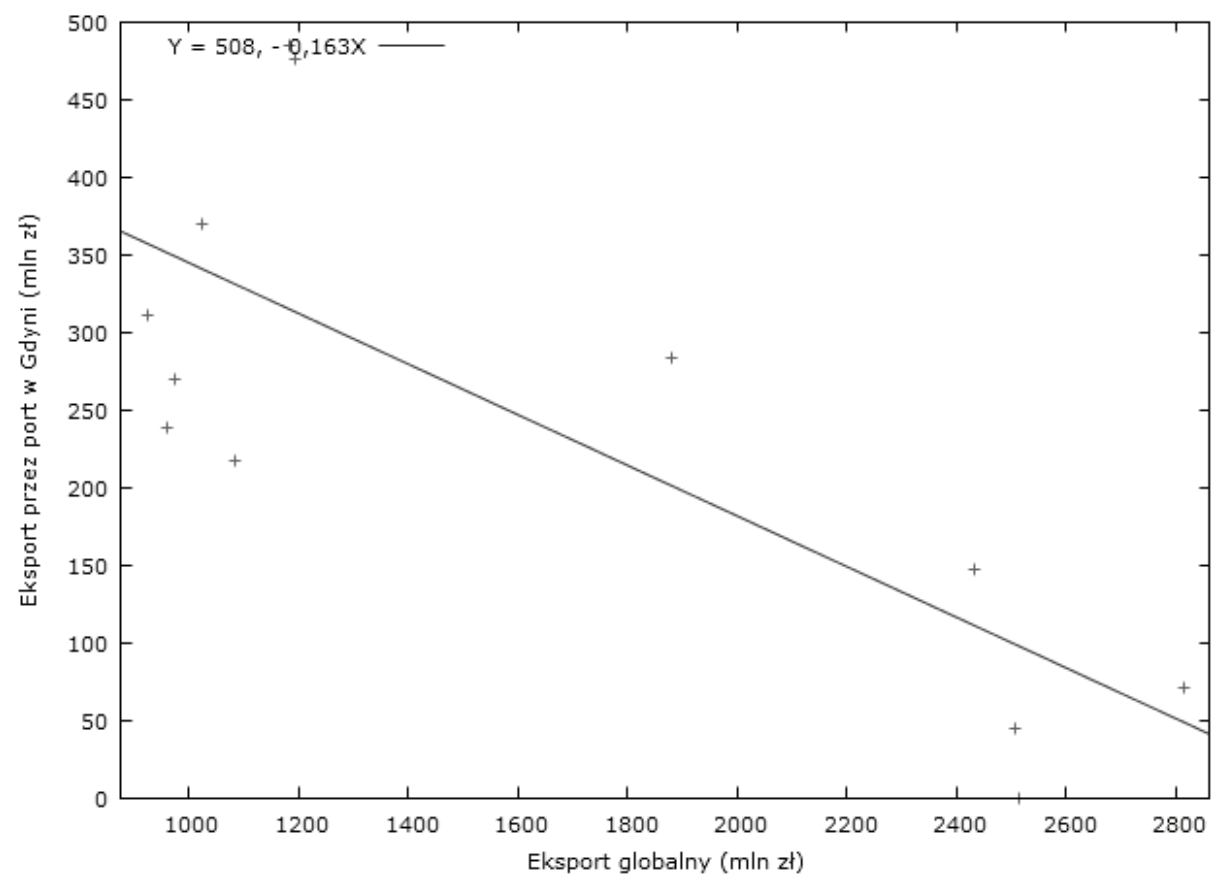

Wykres 10 przedstawia ujemną relację między zmiennymi. W latach 1927 -1938 wzrost eksportu globalnego sprzyjał spadkowi eksportu gdyńskiego. Co więcej, wzrost wywozu globalnego o $1 \mathrm{mln}$ zł decydował o spadku eksportu przez Gdynię o 0,163 mln zł. Zależność udało się oszacować w 59,3\% $\left(\mathrm{R}^{2}=0,593290\right)$.

\subsection{Polski eksport globalny a eksport przez port w Gdańsku}

W kolejnym przypadku, również dotyczącym okresu 1927-1938 ( $\mathrm{n}=12)$, badaniu zostanie poddany wpływ eksportu globalnego (zmienna niezależna $X$ ) na eksport przez Gdańsk (zmienna zależna Y). Hipoteza zerowa odrzuca możliwość tego typu związku, w przeciwieństwie do hipotezy alternatywnej. Pytanie jest następujące: czy wzrost polskiego eksportu globalnego sprzyjał wzrostowi eksportu gdańskiego w latach 1927-1938?

Współczynnik korelacji jest równy 0,9851, zaś wartość krytyczna (przy dwustronnym $5 \%$ obszarze krytycznym) wynosi 0,5760 dla $n=12$. Istnieją więc podstawy do odrzucenia hipotezy zerowej i sformułowania wniosku, iż między zmiennymi istnieje związek dodatni - w latach 1927-1938 wzrost eksportu globalnego wpływał na wzrost wywozu przez Gdańsk. Ponadto, jest to związek bardzo silny, ponieważ wartość współczynnika jest zbliżona do 1 . 
Wykres 11 ukazuje dodatni charakter relacji-zmienne X i Y wzrastają w tym samym kierunku. W latach 1927-1938 wzrost wywozu globalnego Polski wpływał na wzrost eksportu gdańskiego, przy czym zmiana tego pierwszego o $1 \mathrm{mln}$ zł sprzyjała zwiększeniu wywozu przez Gdańsk o 0,226 mln zł. Wpływ ten został oszacowany w $97 \%\left(\mathrm{R}^{2}=0,970384\right)$.

Wykres 11. Eksport przez port w Gdańsku względem eksportu globalnego (opracowanie własne)

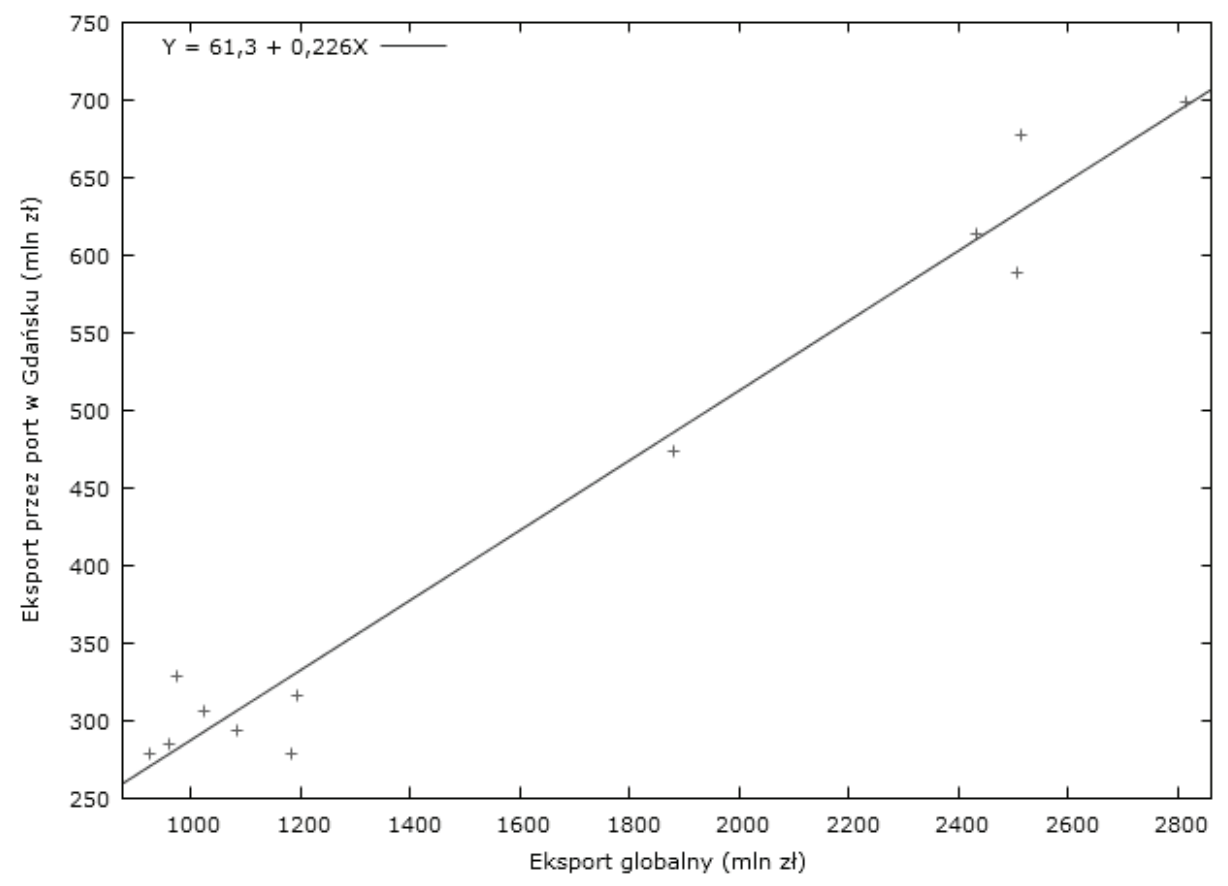

Badania zawarte $\mathrm{w}$ punktach 2.6.-2.7. pozwalają sformułować następujący wniosek: im więcej Polska eksportowała w latach 1927-1938, tym większy wywóz odbywał się przez Gdańsk, a mniejszy przez Gdynię. Konkluzja jest zatem podobna do tej, która dotyczyła importu (por.: pkt. 2.4.-2.5.). Jest to o tyle ciekawe, iż budowa portu w Gdyni, który na przełomie lat dwudziestych i trzydziestych wciąż był rozbudowywany, miała docelowo służyć odstąpieniu od handlu gdańskiego na rzecz wymiany przez Gdynię. W tym kontekście należy pogłębić analizę, co nastąpi w dalszej części rozważań (pkt. 2.8.-2.9.).

\subsection{Udział importu przez porty w Gdyni i Gdańsku w polskim imporcie globalnym}

Ze względu na dostępność danych, podobnie jak we wcześniejszych przypadkach, badanie dotyczyć będzie okresu 1927-1938. Jego celem jest zaś odpowiedź na 
pytanie: jaki był udział importu przez porty w Gdyni i Gdańsku w polskim imporcie globalnym w tym okresie? W tym celu sporządzono tabelę 1 .

Tabela 1

Udział importu przez porty w Gdyni i Gdańsku w polskim imporcie globalnym w latach 1927-1938

\begin{tabular}{||c|c|c|}
\hline Rok & $\begin{array}{c}\text { Udział importu przez port } \\
\text { w Gdyni w imporcie globalnym (w \%) }\end{array}$ & $\begin{array}{c}\text { Udział importu przez port } \\
\text { w Gdańsku w imporcie globalnym (w \%) }\end{array}$ \\
\hline 1927 & 0,00 & 25,07 \\
\hline 1928 & 1,01 & 26,41 \\
\hline 1929 & 2,06 & 25,49 \\
\hline 1930 & 3,74 & 21,15 \\
\hline 1931 & 7,22 & 17,92 \\
\hline 1932 & 15,43 & 20,65 \\
\hline 1933 & 35,91 & 14,99 \\
\hline 1934 & 48,19 & 11,76 \\
\hline 1935 & 52,38 & 8,94 \\
\hline 1936 & 57,63 & 7,08 \\
\hline 1937 & 57,50 & 7,97 \\
\hline 1938 & 53,69 & 7,54 \\
\hline \hline
\end{tabular}

Opracowanie własne.

Tabela 1 obrazuje dwie tendencje w zakresie znaczenia portów w Gdyni i Gdańsku dla polskiego importu w latach 1927-1938. O ile rola Gdyni stopniowo rosła (począwszy od $0 \%$, a skończywszy na ponad 50\%), o tyle udział Gdańska stale spadal z około 25\% do około 7\%. Znaczący byl przy tym 1933 rok, kiedy udzial Gdyni w imporcie globalnym przewyższył (i to ponad dwukrotnie) udział Gdańska. Zjawiska te stanowią dowód na to, jak duże znaczenie dla polskiego handlu zagranicznego miało wybudowanie portu w Gdyni. Wzrastający udział tego ośrodka w polskim imporcie świadczy również o rozwoju samego portu. $Z$ drugiej strony, jest to przejaw tendencji polegającej na stopniowej rezygnacji z użytkowania portu w nienależącym do Polski Gdańsku na rzecz Gdyni (w zakresie przywozu). Warto podkreślić fakt, iż udział Gdyni w imporcie globalnym w 1938 roku (53,69\%) przekroczył ponad dwukrotnie udział Gdańska w owym imporcie w 1927 roku. 
Wykres 12. Relacje między importem przez Gdynię i Gdańsk w latach 1927-1938 (opracowanie własne)

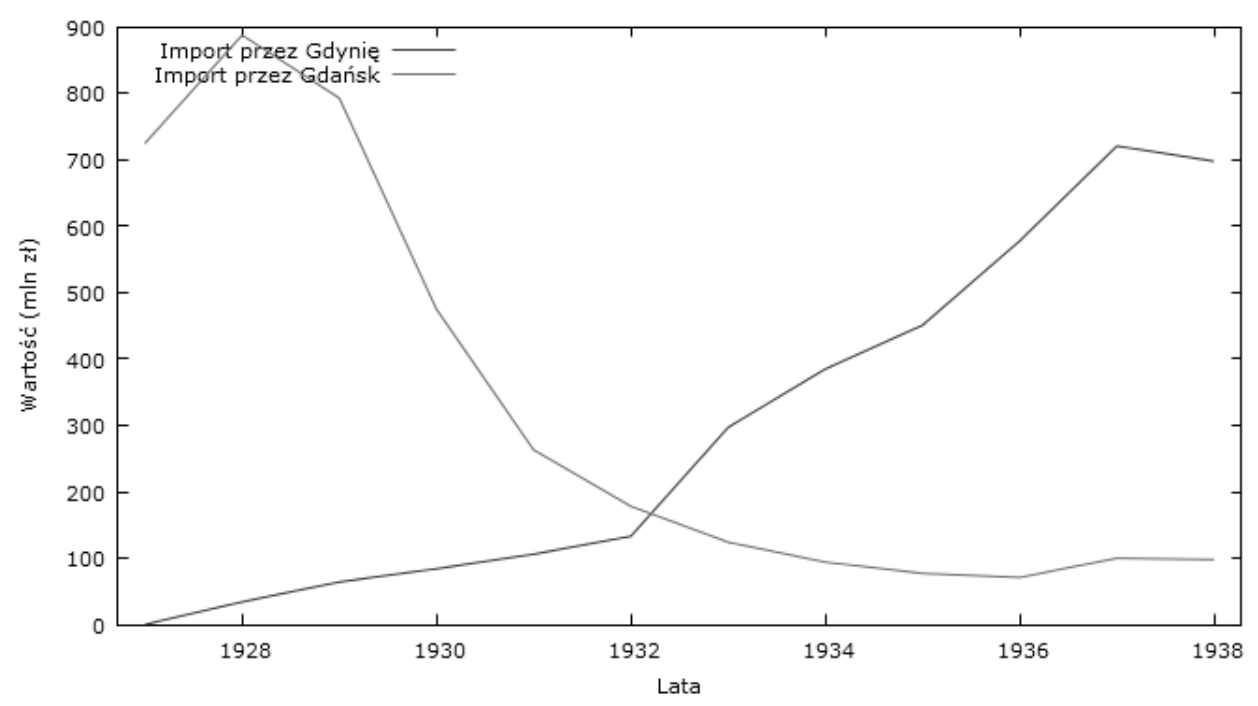

Mimo że wykres 12 dotyczy relacji między importem przez porty w Gdyni i Gdańsku bez uwzględnienia importu globalnego oraz jest wyrażony w liczbach bezwzględnych (mln zł), obrazuje tendencje, o których była mowa powyżej. W latach 1927-1938 Gdańsk stracił swoje importowe znaczenie dla polskiej gospodarki na rzecz Gdyni. Przełomowy był 1933 rok, kiedy przez Gdynię importowano towary o wartości ponad dwukrotnie większej niż przez Gdańsk (odpowiednio: 297 i 124 mln zł; por.: Aneks). Jest to o tyle ciekawe, że w okresie tym przez Gdynię importowano towary o łącznej wartości $3551 \mathrm{mln}$ zł, podczas gdy przez Gdańsk - 3886 mln zł (por.: Aneks). Jak się jednak okazuje, przewaga drugiego portu jest pozorna.

\subsection{Udzial eksportu przez porty w Gdyni i Gdańsku w polskim eksporcie globalnym}

Podobne badanie należy przeprowadzić dla wywozu przez Gdynię i Gdańsk w latach 1927-1938. Umożliwi to odpowiedź na następujące pytanie: jaki był udział eksportu przez porty w Gdyni i Gdańsku w polskim eksporcie globalnym w omawianym okresie? 
Udział eksportu przez porty w Gdyni i Gdańsku w polskim eksporcie globalnym w latach 1927-1938

\begin{tabular}{||c|c|c|}
\hline Rok & $\begin{array}{c}\text { Udział eksportu przez port } \\
\text { w Gdyni w eksporcie globalnym (w \%) }\end{array}$ & $\begin{array}{c}\text { Udział eksportu przez port } \\
\text { w Gdańsku w eksporcie globalnym (w \%) }\end{array}$ \\
\hline 1927 & 0,00 & 26,92 \\
\hline 1928 & 1,79 & 23,44 \\
\hline 1929 & 2,52 & 24,85 \\
\hline 1930 & 6,04 & 25,24 \\
\hline 1931 & 15,06 & 25,17 \\
\hline 1932 & 20,02 & 27,03 \\
\hline 1933 & 24,90 & 29,58 \\
\hline 1934 & 27,69 & 33,64 \\
\hline 1935 & 33,62 & 30,05 \\
\hline 1936 & 36,06 & 29,82 \\
\hline 1937 & 39,83 & 26,44 \\
\hline 1938 & 40,93 & 23,46 \\
\hline \hline
\end{tabular}

Opracowanie własne.

Tabela 2 dostarcza nieco innych konkluzji niż tabela 1 . Chociaż w latach 1927-1938 również można zaobserwować stały wzrost udziału Gdyni w polskim eksporcie (od $0 \%$ do ponad $40 \%$ ), to jednak nie odbywalo się to takim kosztem Gdańska, jak w przypadku importu. Mimo że udział Gdyni przekroczył udzial Gdańska w 1935 roku (odpowiednio: 33,62\% i 30,05\%), to jednak udział tego ostatniego utrzymywał się na względnie stałym poziomie (wahania od $23,44 \%$ do 33,64\%). Można zatem stwierdzić, iż budowa portu w Gdyni nie osłabiła eksportowej roli portu w Wolnym Mieście dla polskiej gospodarki.

Wykres 13 przedstawia relacje między eksportem przez Gdynię i Gdańsk w latach 1927-1938. Wartości są wyrażone w liczbach bezwzględnych. Wykres koresponduje $\mathrm{w}$ pewnej mierze $\mathrm{z}$ tabelą 2 . Wynika $\mathrm{z}$ niego, iż $\mathbf{w}$ omawianym okresie wzrosła znacznie wartość eksportu przez Gdynię. Z kolei wartość wywozu przez Gdańsk spadła (z 677 do 278 mln zl; por.: Aneks). W 1935 roku wielkość wywozu przez Gdynię przekroczyła wysokość eksportu przez gdański port (odpowiednio: 311 i 278 mln zl; por.: Aneks). Mimo to trudno stwierdzić utratę przez Gdańsk eksportowego znaczenia dla polskiej gospodarki, skoro 
w latach 1932-1938 wywóz gdański utrzymywał się na względnie stałym poziomie (ok. 300 mln zł), choć niższym niż w latach 1927-1932. Co więcej, w latach 1927-1938 przez Gdańsk eksportowano towary o łącznej wartości 5134 mln zł, zaś przez Gdynię - 2914 mln zł (por.: Aneks). Fakty te potwierdzają omówiony wcześniej trend, zobrazowany w tabeli 2.

Wykres 13. Relacje między eksportem przez Gdynię i Gdańsk w latach 1927-1938 (opracowanie własne)

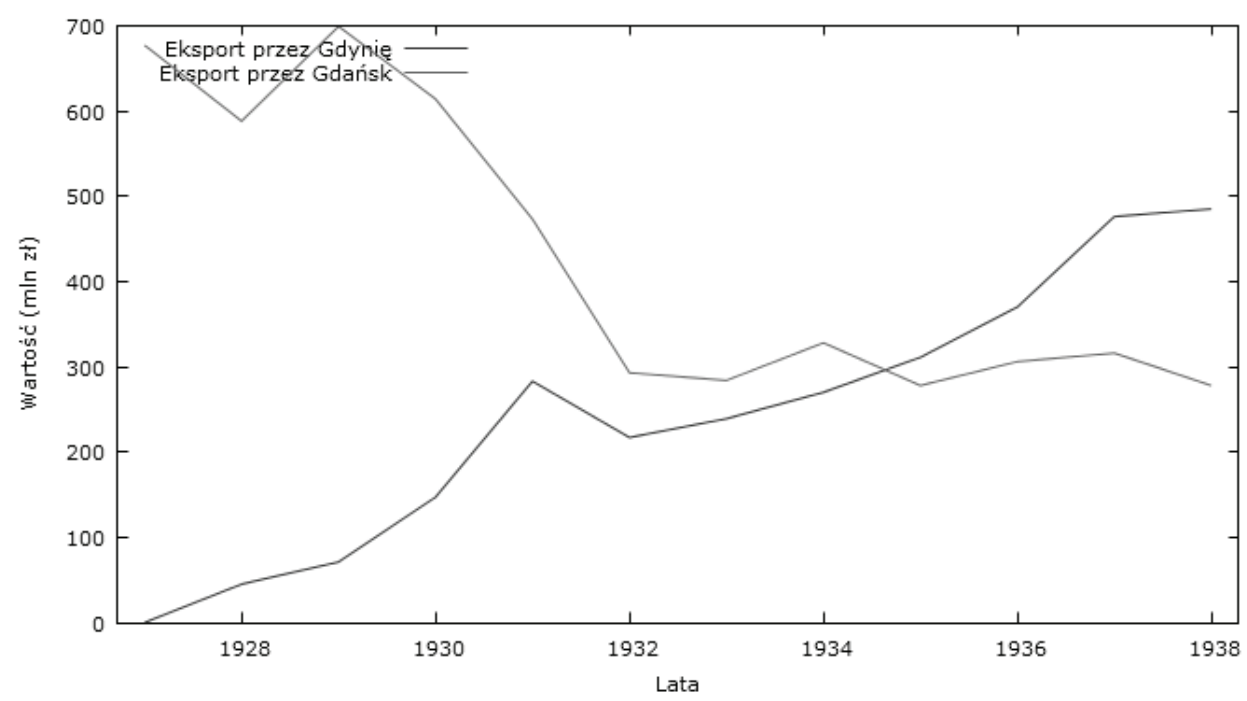

\subsection{Struktura towarowa polskiego importu}

Dane dla struktury towarowej importu obejmują lata 1922-1934. Klasyfikacja grup towarów dla importu i eksportu została bowiem oparta na obowiązującej wówczas konwencji brukselskiej z 31 grudnia 1913 roku $^{16}$. W 1935 roku nastąpiła zmiana zasad klasyfikacji. Odtąd strukturę towarową określano według nowego podziału ustalonego przez Komitet Ekspertów Statystycznych przy Lidze Narodów ${ }^{17}$. Połączenie tych dwóch klasyfikacji zaburzyłoby wyniki badania. Obejmie ono zatem wyłącznie okres 1922-1934. Trzynastoletni przedział czasu wydaje się jednak wystarczający, aby uchwycić specyfikę struktury towarowej handlu zagranicznego II Rzeczypospolitej.

${ }^{16}$ Maty Rocznik..., 1930, s. 65, przyp. a.

${ }^{17}$ Z. Laundau, J. Tomaszewski, dz. cyt., t. III: Wielki kryzys: 1930-1935, Książka i Wiedza, Warszawa 1982, s. 391; Z. Landau, J. Tomaszewski, dz. cyt., t. IV: Lata ..., s. 499-500; Mały Rocznik..., 1936, s. 106. 
Pytanie badawcze jest następujące: które grupy towarów dominowały w strukturze polskiego importu? Analiza struktury towarowej zostanie przeprowadzona w oparciu o wybrane miary tendencji centralnej obliczone przez program Gretl.

Tabela 3

Struktura towarowa importu Polski w latach 1922-1934. Statystyki opisowe

\begin{tabular}{||l|c|c|c|c|c||}
\hline & $\begin{array}{c}\text { Zwierzęta } \\
\text { żywe } \\
\text { (mln zł) }\end{array}$ & $\begin{array}{c}\text { Artykuły spo- } \\
\text { żywcze i na- } \\
\text { poje (mln zł) }\end{array}$ & $\begin{array}{c}\text { Surowce } \\
\text { i półfabrykaty } \\
\text { (mln zł) }\end{array}$ & $\begin{array}{c}\text { Wyroby } \\
\text { gotowe } \\
\text { (mln zł) }\end{array}$ & $\begin{array}{c}\text { Złoto i srebro } \\
\text { nieobrobione, } \\
\text { monety zło- } \\
\text { te i srebrne } \\
\text { (mln zł) }\end{array}$ \\
\hline Średnia & 3,154 & 324,077 & 788,615 & 867,000 & 53,462 \\
\hline Mediana & 2,000 & 271,000 & 759,000 & 887,000 & 20,000 \\
\hline Minimum & 1,0 & 86,0 & 376,0 & 269,0 & 1,0 \\
\hline Maksimum & 13,0 & 698,0 & 1300,0 & 1483,0 & 307,0 \\
\hline
\end{tabular}

Opracowanie własne.

Dane obejmują lata 1922-1934, zatem $N=13$. W przypadku 5 pozostałych lat odnotowano braki danych (por.: komentarz powyżej). Z tabeli 3 wynika, że największy udział w polskim imporcie miały wówczas wyroby gotowe (suma $=11271 \mathrm{mln} \mathrm{zf}^{18} ;$ średnia $=867 \mathrm{mln} \mathrm{zł}$; mediana $\left.=887 \mathrm{mln} \mathrm{zł}\right)$ oraz surowce i półfabrykaty $($ suma $=10252 \mathrm{mln}$ zł; średnia $=788,615 \mathrm{mln} \mathrm{zk}$; mediana $=759 \mathrm{mln}$ zł). Z kolei najmniej importowano zwierząt żywych (suma $=41 \mathrm{mln} z ł ;$ średnia $=3,154 \mathrm{mln}$ zł; mediana $=2 \mathrm{mln}$ zł). Dominujący udział wyrobów gotowych w imporcie świadczy o niskim poziomie rozwoju gospodarczego Polski międzywojennej ${ }^{19}$.

\subsection{Struktura towarowa polskiego eksportu}

Analogicznie należy zbadać strukturę towarową wywozu Polski i odpowiedzieć na pytanie: które grupy towarów dominowały w strukturze polskiego eksportu w latach 1922-1934?

\footnotetext{
${ }^{18}$ Wszystkie sumy w pkt. 2.10. i 2.11. zaczerpnięto z Aneksu.

${ }^{19}$ Por.: P. Samecki, Handel międzynarodowy. Elementy polityki handlowej, [w:] Podstawy ekonomii, red. R. Milewski, E. Kwiatkowski, WN PWN, Warszawa 2005, s. 433-434; P. A. Samuelson, W.D. Nordhaus, Ekonomia, t. 2, WN PWN, Warszawa 2002, s. 411-426.
} 
Struktura towarowa eksportu Polski w latach 1922-1934. Statystyki opisowe

\begin{tabular}{||l|c|c|c|c|c|}
\hline \hline & $\begin{array}{c}\text { Zwierzęta } \\
\text { żywe } \\
\text { (mln zł) }\end{array}$ & $\begin{array}{c}\text { Artykuły spo- } \\
\text { żywcze i na- } \\
\text { poje (mln zł) }\end{array}$ & $\begin{array}{c}\text { Surowce } \\
\text { i półfabrykaty } \\
\text { (mln zł) }\end{array}$ & $\begin{array}{c}\text { Wyroby } \\
\text { gotowe } \\
\text { (mln zł) }\end{array}$ & $\begin{array}{c}\text { Złoto i srebro } \\
\text { nieobrobione, } \\
\text { monety zło- } \\
\text { te i srebrne } \\
\text { (mln zł) }\end{array}$ \\
\hline Średnia & 107,077 & 442,692 & 935,000 & 435,308 & 28,723 \\
\hline Mediana & 88,000 & 512,000 & 1004,000 & 448,000 & 1,000 \\
\hline Minimum & 3,0 & 152,0 & 383,0 & 225,0 & 0 \\
\hline Maksimum & 232,0 & 715,0 & 1454,0 & 744,0 & 234,0 \\
\hline
\end{tabular}

Opracowanie własne.

Na podstawie statystyk opisowych zawartych w tabeli 4 można stwierdzić, że największy udział w polskim eksporcie miały wówczas surowce i półfabrykaty $($ suma $=12155 \mathrm{mln} \mathrm{zł}$; średnia $=935 \mathrm{mln} \mathrm{zł}$; mediana $=1004 \mathrm{mln} \mathrm{zl})$. Taka struktura towarowa eksportu potwierdza weześniejszy wniosek o słabym rozwoju gospodarczym Polski międzywojennej. Należy dodać, że istotny udział w eksporcie miały również artykuły spożywcze i napoje (suma $=5755 \mathrm{mln}$ zł; średnia $=442,692 \mathrm{mln} \mathrm{zl}$; mediana $=512 \mathrm{mln} \mathrm{zl}$ ) oraz wyroby gotowe (suma $=5659 \mathrm{mln}$ zł; średnia $=435,308 \mathrm{mln} \mathrm{zł}$; mediana $=448 \mathrm{mln} \mathrm{zł}$ ). Z kolei najmniej wywożono wówczas złota i srebra (suma $=373,4 \mathrm{mln}$ zł; średnia $=28,723 \mathrm{mln}$ zł; mediana $=1 \mathrm{mln} \mathrm{zl})$.

\section{Konfrontacja wyników analizy z wybraną literaturą przedmiotu}

Wyniki przeprowadzonej analizy statystycznej niektórych aspektów handlu zagranicznego Polski międzywojennej należy skonfrontować z wybraną literaturą przedmiotu. Historiografia gospodarcza dostarcza bowiem tez i konkluzji korespondujących z pewnymi zagadnieniami podejmowanymi w niniejszym studium. Wydaje się, że najcenniejsze pod tym względem są syntezy poświęcone dziejom gospodarczym Polski. Kwerendę ograniczyłem do wybranych prac opublikowanych po 1945 roku, ponieważ podejmują problematykę okresu międzywojennego w sposób całościowy.

W okresie międzywojennym relacje między polskim importem a eksportem kształtowały się w sposób dynamiczny (por: pkt. 2.1.). Jak już wspomniano, największa częstotliwość zmian wystąpiła w latach dwudziestych. Wynikało to $\mathrm{z}$ procesów gospodarczych zachodzących w Polsce po odzyskaniu niepodległości, które objęły: proces odbudowy kraju, gospodarkę wojenną doby konfliktu 
z bolszewicką Rosją, kryzys inflacyjny (1918-1923), kryzys poinflacyjny oraz ożywienie koniunktury (1924-1929) ${ }^{20}$.

Bardziej jednolite pod tym względem były lata trzydzieste. Lata 1930-1936, charakteryzujące się dodatnim bilansem handlowym, obejmują okres wielkiego kryzysu ekonomicznego. Podobnie jak w innych krajach, władze polskie faworyzowały wówczas eksport. Dokonywało się to dzięki: systemowi premii eksportowej (obejmującemu m.in. produkty hutnicze, chemiczne i lekkie), subsydiowaniu wywozu płodów rolnych (szczególnie zbóż), „zwrotom cel” za bekony i szynki, ciągłemu zwiększaniu nakładów budżetowych przeznaczonych na politykę eksportową, umożliwieniu stosowania przez eksporterów cen dumpingowych (np. cukru i węgla), państwowym kredytom eksportowym, organizacjom gospodarczym promującym krajową produkcję i przyznającym eksporterom różne formy wsparcia, standaryzacji (kontroli jakości) produktów wywozowych (np. masła) czy też kartelizacji eksportu (obejmującej m.in. zboża, drewno, cukier, naftę, węgiel). Jednocześnie nakładano liczne ograniczenia importowe, które miały służyć m.in. spłacie zobowiązań wobec innych państw. Wzmocniono ochronę celną rodzimego rynku poprzez: podwyższenie ceł przywozowych, wprowadzenie maksymalnej taryfy celnej w handlu z Niemcami, ogłoszenie nowej taryfy celnej (1933), rozszerzenie listy towarów obłożonych reglamentacją przywozu. Stosowano również umowy clearingowe zakładające handel oparty na zerowym bilansie płatniczym (innymi słowy, strony umowy importowały dokładnie tyle, ile eksportowały). Działania te można uznać za skuteczne. Rzeczpospolita odnotowała bowiem saldo dodatnie, mimo że w latach 1929-1934 wartość obrotów polskiego handlu zagranicznego spadła o ok. 70\%, obniżyły się wartości importu i eksportu, a udział kraju w światowych obrotach handlowych zmniejszył się z 1\% w $1928 \mathrm{r}$. do 0,8\% w $1935 \mathrm{roku}^{21}$.

W okresie interwencjonizmu państwowego - wskutek poprawy koniunktury w gospodarce światowej i polskiej - wzrosła wartość obrotów handlu zagranicznego (o 39,1\% w 1938 r. W stosunku do 1935 r.). W 1936 roku wprowadzono reglamentację dewizową. Odtąd państwo przejęło kontrolę nad całym obrotem handlowym z zagranicą. Występujące w latach 1937-1938 saldo ujemne było w znacznej mierze konsekwencją etatystycznej polityki rządu. Wskutek inten-

${ }^{20}$ Por.: Z. Landau, J. Tomaszewski, dz. cyt., t. I-II, Książka i Wiedza, Warszawa 1967, 1971; M.M. Drozdowski, Gospodarka Drugiej Rzeczypospolitej, [w:] Polska odrodzona 1918-1939. Państwo, społeczeństwo, kultura, red. J. Tomicki, Wiedza Powszechna, Warszawa 1982, s. 422.

${ }^{21}$ W. Rusiński, Rozwój gospodarczy ziem polskich w zarysie, Książka i Wiedza, Warszawa 1963, s. 370, 386; tenże, Zarys historii gospodarczej Polski na tle dziejów gospodarczych powszechnych, PWN, Warszawa 1986, s. 255-256, tab. 9; Z. Landau, J. Tomaszewski, dz. cyt., t. III: Wielki..., s. 388389, tabl. 81; 392-394; M. M. Drozdowski, dz. cyt., s. 444-445; J. Skodlarski, Zarys historii gospodarczej Polski, Warszawa 2005, s. 283-284; W. Morawski, dz. cyt., s. 209-210. W ekonomii postrzeganie dodatniego bilansu handlowego jako korzystnego dla państwa oraz ujemnego jako niekorzystnego nie jest do końca właściwe. Na przykład, okazuje się, że saldo ujemne może mieć pozytywny wpływ na gospodarkę i odwrotnie (por.: P. A. Samuelson, W. D. Nordhaus, dz. cyt., s. 426-431). 
sywnego uprzemysłowienia i wzrostu krajowej produkcji, importowano znacznie więcej surowców, dóbr inwestycyjnych, maszyn i sprzętu wojskowego. Co więcej, utrzymywanie parytetu złotego wpłynęło na konkurencyjność rodzimych towarów na arenie międzynarodowej. Obroty handlowe Polski do 1939 roku były jednak znacznie niższe od obrotów sprzed kryzysu. Rząd nie zdołał wpłynąć na wzrost eksportu. Był to skutek nieefektywnej organizacji handlu zagranicznego, dumpingu praktykowanego przez inne państwa, zbyt wysokich cen niektórych polskich dóbr. Co więcej, w 1938 roku na rynkach światowych spadły ceny produktów rolnych. Na eksport negatywnie wpłynął również anschluss Austrii z marca 1938 roku. Rząd polski, prawdopodobnie z obawy o zbyt duże uzależnienie ekonomiczne od Niemiec, ograniczył obroty handlowe z III Rzeszą, wyznaczając ich maksymalną wartość (300 mln zł). Co więcej, o zmniejszeniu wymiany handlowej z Austrią miała zadecydować autarkiczna polityka Berlina. W konsekwencji, Polska wywoziła do Austrii mniej węgla i drewna ${ }^{22}$.

Analiza wykazała, że na przestrzeni lat 1927-1938 wzrastał udział Gdyni w polskim imporcie i eksporcie przy jednoczesnym spadku udziału Gdańska w przywozie oraz względnie stałym udziale Wolnego Miasta w wywozie (por.: pkt. 2.8.-2.9.). Owe swoiste „przejście” od Gdańska do Gdyni w połowie lat trzydziestych jest dostrzegalne w niektórych opracowaniach. Według Władysława Rusińskiego, o budowie Gdyni, jej rozwoju i znaczeniu dla handlu zagranicznego - oprócz przyczyn politycznych - zadecydował fakt, iż możliwości portu gdańskiego nie nadążały za polskimi potrzebami handlowymi ${ }^{23}$. Co więcej, miała się $\mathrm{w}$ to wpisywać również polska racja stanu i stały wzrost obrotów towarowych polskiego handlu ${ }^{24}$.

Jak zauważył Kazimierz Piwarski, od początku istnienia Wolnego Miasta Gdańska dały się zauważyć wymierne korzyści jego relacji ekonomicznych z Polską. W 1912 roku liczba statków przypływających i odpływających z portu wyniosła 5 966, w 1925 roku - 7 944, w 1926 roku - 11 870, w 1927 roku - 13892. Tonaż statków w latach 1912-1930 wzrósł z kolei o 322\%. Sam Gdańsk był w tym okresie najlepiej rozwijającym się portem bałtyckim. Przed I wojną światową do portu zawijały statki 10 krajów europejskich, natomiast po 1918 roku odnotowano aż 32 bandery ${ }^{25}$. Przełom nastąpił - według K. Piwarskiego - w 1937 roku, gdy nowy port w Gdyni odnotował większe obroty handlowe niż Szczecin i Gdańsk. Tym samym, wysunął się nad inne porty bałtyckie. Miała to być konsekwencja przeobrażenia, jakie dokonało się w polskim handlu, polegającego na odejściu od transportu lądowego na rzecz morskiego. Gdynia posiadała najnowocześniejsze

${ }^{22}$ Gospodarcze skutki Anschlussu, „Polityka Gospodarcza”, 25.03.1938, nr 59, s. 6; W. Rusiński, Zarys ..., s. 277; Z. Landau, J. Tomaszewski, dz. cyt., t. IV: Lata ..., s. 480-481, 495, tabl. 84; 496-497, 499; M. M. Drozdowski, dz. cyt., s. 449, 461; J. Skodlarski, dz. cyt., s. 312.

${ }^{23}$ W. Rusiński, Rozwój..., s. 371.

${ }^{24}$ Tenże, Zarys ..., s. 231.

${ }^{25}$ K. Piwarski, dz. cyt., s. 215. 
urządzenia portowe spośród innych portów bałtyckich. Była ponadto położona dogodniej niż Gdańsk - bezpośrednio nad morzem. Tym samym, większa część polskiego handlu została skierowana na drogę morską, a statki zagraniczne w coraz większej liczbie i o coraz wyższym tonażu zawijały do gdyńskiego portu ${ }^{26}$. Przejawem tej tendencji są liczby przytoczone przez Mariana Marka Drozdowskiego, który zwrócił uwagę, iż w 1930 roku 71,8\% obrotów handlowych Polski było realizowanych lądem, a 28,2\% - drogą morską, w tym 4,9\% przez port w Gdyni. Z kolei w 1935 roku drogą lądową zrealizowano 37,4\% obrotów, zaś morską $62,6 \%$, w tym $42,7 \%$ przez Gdynię $e^{27}$.

W. Rusiński stwierdził, iż mimo problemów związanych z użytkowaniem portu w Gdańsku, jego obroty permanentnie rosły. Do tego stopnia, że w 1928 roku osiągnęły dwukrotność poziomu z 1913 roku. Nie zmienia to faktu, iż znaczenie Gdyni w handlu zagranicznym stopniowo rosło. W 1928 roku tamtejszy ruch przeładunkowy wyniósł ponad $1 \mathrm{mln}$ ton $^{28}$. Na początku lat trzydziestych, dzięki rozbudowie Gdyni, dokonała się zmiana niektórych kierunków polskiej wymiany zagranicznej - wzrósł udział obrotów z krajami pozaeuropejskimi ${ }^{29}$. Spostrzeżenia te korespondują - w jakiejś mierze - z wynikami analizy. Stopniowy wzrost znaczenia Gdyni w handlu zagranicznym nie oznaczał załamania pozycji Gdańska w wymianie zewnętrznej.

Mimo to władze Wolnego Miasta zdawały sobie sprawę, iż rosnący udział Gdyni w polskiej wymianie zagranicznej zagraża gdańskim interesom. Przejawem tego może być chociażby fakt, iż 9 maja 1930 roku tamtejszy Senat przedłożył Wysokiemu Komisarzowi Ligi Narodów wniosek o zobowiązanie strony polskiej do pełnego wykorzystania urządzeń w porcie gdańskim ${ }^{30}$. Przywołany incydent wpisywał się w szerszy kontekst konfliktów z Polską narastających od lat dwudziestych i wynikających z zacieśniania przez Wolne Miasto związków z Niemcami.

Analiza dowiodła, iż cechą charakterystyczną struktury towarowej polskiego handlu zagranicznego Polski była dominacja wyrobów gotowych oraz surowców i półfabrykatów w imporcie (pkt. 2.10.) oraz surowców i półfabrykatów w eksporcie (pkt. 2.11.). Znajduje to potwierdzenie w literaturze przedmiotu ${ }^{31}$. Jest to jednocześnie specyfika krajów słabo rozwiniętych, rolniczo-surowcowych. W kontekście handlu zagranicznego zaliczała się do nich Polska międzywojenna ${ }^{32}$.

${ }^{26}$ Tamże, s. 219-220.

${ }^{27}$ M. M. Drozdowski, $d z$. cyt, s. 445.

${ }^{28}$ W. Rusiński, Zarys..., s. 231.

${ }^{29}$ Z. Landau, J. Tomaszewski, dz. cyt., t. III: Wielki..., s. 391.

${ }^{30}$ Tamże, s. 368.

${ }^{31}$ W. Rusiński, Rozwój ..., s. 370-371; tenże, Zarys ..., s. 235-236, 277-278; Z. Landau, J. Tomaszewski, dz. cyt., t. I: W dobie..., s. 343; Z. Landau, J. Tomaszewski, dz. cyt., t. II: Od Grabskiego..., s. 295-296; Z. Landau, J. Tomaszewski, dz. cyt., t. III: Wielki..., s. 391-392; Z. Landau, J. Tomaszewski, dz. cyt., t. IV: Lata ..., s. 499; M. M. Drozdowski, dz. cyt., s. 445.

${ }^{32}$ Z. Landau, J. Tomaszewski, dz. cyt., t. I: W dobie..., s. 343; Z. Landau, J. Tomaszewski, dz. cyt., t. II: Od Grabskiego..., s. 296; W. Rusiński, Zarys..., s. 277; D. Bębnowski, Bilans ..., s. 24. 
Potwierdzeniem tego stanu rzeczy może być przykładowo stały spadek udziału gotowych wyrobów w wywozie - z 27\% w 1924 roku do 10\% w 1928 roku ${ }^{33}$.

\section{Konkluzje}

Jedynie niektóre rezultaty przeprowadzonej analizy statystycznej znajdują potwierdzenie - w dodatku częściowe - w wybranej literaturze przedmiotu. Dotyczy to 5 spośród 11 zbadanych problemów:

- import a eksport Polski (pkt. 2.1.), przy czym opracowania charakteryzują dynamikę relacji między przywozem a wywozem poprzez saldo bilansu handlowego, nie poruszając kwestii ich wzajemnych zależności;

- udział importu przez porty w Gdyni i Gdańsku w polskim imporcie globalnym (pkt. 2.8.);

- udział eksportu przez porty w Gdyni i Gdańsku w polskim eksporcie globalnym (pkt. 2.9.);

- struktura towarowa polskiego importu (pkt. 2.10.);

- struktura towarowa polskiego eksportu (pkt. 2.11.).

Należy jednak zauważyć, iż wykorzystana literatura przedmiotu odnosi się wyłącznie do wątków tematycznych podjętych w powyższych 5 przypadkach, a nie do badanych korelacji. W kontekście handlu zagranicznego II Rzeczypospolitej autorzy skupiają się bowiem najczęściej na zagadnieniach importu, eksportu, bilansu handlowego oraz struktury towarowej i geograficznej. Kwestie te są jednak omawiane w przeważającej mierze w sposób deskryptywny bez zagłębiania się w zależności między określonymi aspektami wymiany handlowej. Metody ekonomiczne - jak te wykorzystane w niniejszym artykule - mogą wypełnić lukę w tym zakresie.

W przypadku 6 pozostałych wątków (pkt.: 2.2.-2.3., 2.4.-2.7.) nie udało się znaleźć odniesień w studiowanej literaturze. Konkluzje wynikające z tych analiz można zatem potraktować jako hipotezy stanowiące punkt wyjścia dla dalszych badań. Są one następujące:

- W latach 1924-1931 import w większym stopniu wpływał na obrót handlu krajowego niż odwrotnie (pkt. 2.2.).

- W latach 1924-1931 eksport w większym stopniu wpływał na obrót wymiany wewnętrznej niż odwrotnie (pkt. 2.3.). Jednakże, im więcej Polska eksportowała, tym bardziej wzrastał obrót handlu wewnętrznego. Wniosek ten wynika z porównania wyników analizy w pkt. 2.2. i 2.3.

${ }^{33}$ W. Rusiński, Zarys..., s. 235-236. 
- W latach 1927-1938 wzrost importu globalnego sprzyjał spadkowi importu przez Gdynię (pkt. 2.4.).

- W latach 1927-1938 wzrost importu globalnego generował wzrost importu przez port w Gdańsku (pkt. 2.5.). Na podstawie porównania wyników analizy z pkt. 2.4. i 2.5. można wnioskować, że im więcej Polska importowała w latach 1927-1938, tym więcej wwożono przez Gdańsk, a mniej przez port w Gdyni.

- W latach 1927-1938 wzrost eksportu globalnego powodował spadek eksportu przez port w Gdyni (pkt. 2.6.).

- W latach 1927-1938 wzrost eksportu globalnego wpływał na wzrost eksportu przez Gdańsk (pkt. 2.7.). Porównanie wyników z pkt. 2.6. i 2.7. pozwala jednak stwierdzić, że im więcej Polska eksportowała w latach 1927-1938, tym więcej wywożono przez port w Gdańsku, a mniej przez Gdynię.

- Dodatkową hipotezą niepotwierdzoną w literaturze przedmiotu może być zaobserwowana zależność między importem a eksportem w latach 1922 -1939 (pkt. 2.1.). Analiza wykazała, że - w przypadku występowania przyczynowości, czego nie można jednoznacznie stwierdzić - wywóz w większym stopniu wpływał na przywóz niż odwrotnie.

Należy jednocześnie przypomnieć, iż wszystkie wykazane związki nie muszą mieć charakteru deterministycznego. Korelacja liniowa Pearsona i regresja liniowa nie wykazują bowiem związków przyczynowo-skutkowych. Mimo to, zbadane relacje między zmiennymi poszerzają perspektywę poznania specyfiki polskiego handlu zagranicznego w okresie międzywojennym.

\section{Damian Bębnowski}

\section{THE STATISTICAL ANALYSIS OF SELECTED ASPECTS OF THE FOREIGN TRADE OF THE SECOND POLISH REPUBLIC}

Economic history is an interdisciplinary science, developing in the contact between history and economics, although this kind of studies often needs to refer to the achievements of other disciplines. In the economic history research it seems to be inspiring to use for example economic methods. The aim of this article is to present the results of statistical analysis which was about selected aspects of the Polish foreign trade in the interwar period.

The data are obtained from 'The Small Statistical Yearbook' for years 1930-1939 and cover the period 1922-1939. The tests were conducted using statistical program 'Gretl' and the results were confronted with the selected literature. The analysis concerned the following dependences: import and export in Poland; import and domestic trade turnover in Poland; export and domestic trade turnover in Poland; Polish global import and import through the port of Gdynia; Polish global import and import through the port of Gdansk; Polish global export and export through the port of Gdynia; Polish global export and export through the port of Gdansk. 
There were also researched: the share of import through the ports of Gdynia and Gdansk in Polish global import, the share of export through the ports of Gdynia and Gdansk in Polish global export, the commodity composition of Polish import and export.

For that purpose there were constructed the simple econometric models, based on the method, which is Pearson correlation coefficient. There were used basic descriptive statistics (arithmetic mean and median) and constructed the corresponding graphs and tables.

Słowa kluczowe: handel zagraniczny, II Rzeczypospolita, analiza statystyczna.

Keywords: foreign trade, Second Polish Republic, statistical analysis.

\section{BIBLIOGRAFIA}

Bębnowski D., Bilans handlu zagranicznego II Rzeczypospolitej. Próby przezwyciężania kryzysów, [w:] Wiek XX wiekiem kryzysu? Kryzys człowieczeństwa, czyli ludobójstwa w minionym stuleciu, red. J. Gałuszka, Kraków 2014.

Drozdowski M.M., Gospodarka Drugiej Rzeczypospolitej, [w:] Polska odrodzona 1918-1939. Państwo, społeczeństwo, kultura, red. J. Tomicki, Warszawa 1982.

Dzieje Gdyni, red. R. Wapiński, Wrocław 1980.

Gospodarcze skutki Anschlussu, „Polityka Gospodarcza”, 25.03.1938, nr 59.

Graban M., Gdynia wobec przeobrażeń cywilizacyjnych XX i XXI wieku. Ewolucja czynników rozwoju miasta, Gdynia 2012.

Kałuski M., Polskie dzieje Gdańska do 1945 roku (Zbiór szkiców), Pelplin 2004.

Koop G., Wprowadzenie do ekonometrii, Warszawa 2014.

Kufel T., Ekonometria. Rozwiązywanie problemów z wykorzystaniem programu GRETL, Warszawa 2007.

Kula W., Problemy i metody historii gospodarczej, Warszawa 1983.

Landau Z., Tomaszewski J., Gospodarka Polski międzywojennej 1918-1939, t. 1: W dobie inflacji 1918-1923, Warszawa 1967; t. 3: Wielki kryzys: 1930-1935, Warszawa 1982; t. 4: Lata interwencjonizmu państwowego 1936-1939, Warszawa 1989.

Mały Rocznik Statystyczny, 1930-1939.

Morawski W., Dzieje gospodarcze Polski, Warszawa 2010.

Piwarski K., Dzieje Gdańska w zarysie, Gdańsk 1997.

Program Gretl - http://gretl.sourceforge.net/ oraz http://www.kufel.torun.pl/ (dostęp: 04 II 2016).

Rusiński W., Rozwój gospodarczy ziem polskich w zarysie, Warszawa 1963.

Rusiński W., Zarys historii gospodarczej Polski na tle dziejów gospodarczych powszechnych, Warszawa 1986.

Rutkowski J., Historia gospodarcza Polski, t. 1: Czasy przedrozbiorowe, Poznań 1946.

Samecki P., Handel międzynarodowy. Elementy polityki handlowej, [w:] Podstawy ekonomii, red. R. Milewski, E. Kwiatkowski, Warszawa 2005 .

Samuelson P.A., Nordhaus W. D., Ekonomia, t. 2, Warszawa 2002.

Skodlarski J., Zarys historii gospodarczej Polski, Warszawa 2005.

Sobczyk M., Statystyka, Warszawa 2007.

Topolski J., Metodologia historii, Warszawa 1973. 


\begin{tabular}{|c|c|c|c|c|c|c|c|c|c|c|c|c|}
\hline \multicolumn{3}{|c|}{ 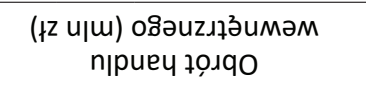 } & & & 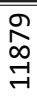 & 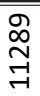 & न & 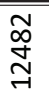 & 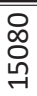 & ํํํ & 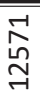 & 吾 \\
\hline \multirow{4}{*}{ 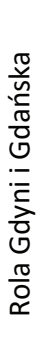 } & \multirow{2}{*}{ 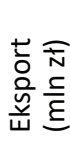 } & ysuepg & & & & & & $\hat{\widehat{\theta}}$ & $\begin{array}{l}\infty \\
\infty \\
\infty\end{array}$ & Яి & $\underset{6}{\Delta}$ & $\stackrel{m}{\mathcal{f}}$ \\
\hline & & e!u^pg & & & & & & 0 & 年 & 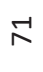 & 字 & $\stackrel{m}{\sim}$ \\
\hline & \multirow{2}{*}{ 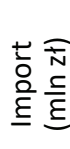 } & ysụepg & & & & & & $\stackrel{\mathscr{N}}{N}$ & $\begin{array}{l}\infty \\
\infty \\
\infty\end{array}$ & กิ & 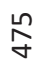 & $\stackrel{n}{\sim}$ \\
\hline & & e!̣upg & & & & & & 0 & mे & ఫ & ১ & 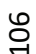 \\
\hline \multirow{10}{*}{ 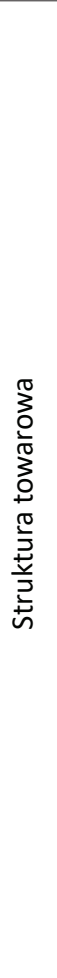 } & \multirow{5}{*}{ 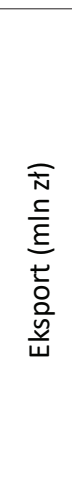 } & 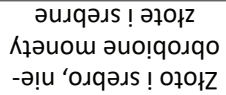 & 0 & 후 & 0 & 0 & 뭉 & -1 & ̋̃ & -1 & $\mathscr{m}$ & -1 \\
\hline & & әмозов КqодКМ & $\begin{array}{l}\infty \\
\infty \\
i n\end{array}$ & $\stackrel{N}{\&}$ & $\stackrel{\infty}{\infty}$ & 옹 & 울 & $\stackrel{-1}{n}$ & ఫ్ర & กี & กิ & $\stackrel{\infty}{\&}$ \\
\hline & & 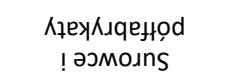 & $\underset{m}{\infty}$ & $\underset{\sim}{\stackrel{\sim}{二}}$ & ষ্ণ & 형 & $\underset{\text { I }}{\mathbb{Z}}$ & 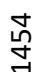 & $\begin{array}{l}\mathscr{\infty} \\
\stackrel{m}{\longrightarrow}\end{array}$ & $\stackrel{-}{n}$ & $\stackrel{\infty}{\text { Oิ }}$ & ర్) \\
\hline & & 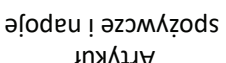 & กี & $\stackrel{\substack{\infty \\
\rightarrow}}{-1}$ & 窝 & 근 & 古 & $\stackrel{9}{G}$ & $\begin{array}{l}\mathscr{N} \\
\text { in }\end{array}$ & $\stackrel{n}{n}$ & สิ & พ \\
\hline & & 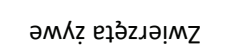 & $\checkmark$ & $m$ & -1 & 咅 & $\stackrel{n}{\rightarrow}$ & ने & $\tilde{n}$ & $\stackrel{\sim}{*}$ & $\infty$ & $\begin{array}{l}\infty \\
\infty\end{array}$ \\
\hline & \multirow{5}{*}{ 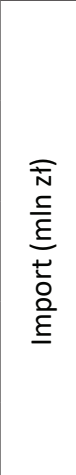 } & 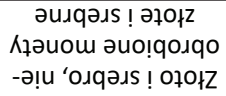 & $\sim$ & $m$ & -1 & N & $m$ & 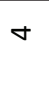 & ôm & ㄱ & 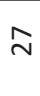 & $\tilde{m}$ \\
\hline & & әмоұов КqодАМ & $\widetilde{\tilde{\sigma}}$ & $\hat{\infty}$ & $\underset{\sim}{\sim}$ & $\underset{\sim}{\infty}$ & $\stackrel{\bullet}{\mathscr{0}}$ & $\underset{\substack{m \\
\rightarrow}}{\stackrel{\overbrace{}}{r}}$ & $\underset{\substack{m \\
⿱ 亠 乂}}{\stackrel{1}{+}}$ & $\underset{\stackrel{\sim}{*}}{\stackrel{\sim}{H}}$ & $\underset{m}{\tilde{c}}$ & $\underset{\infty}{\mathscr{0}}$ \\
\hline & & 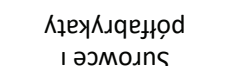 & $\begin{array}{l}6 \\
\qquad \\
6\end{array}$ & 员 & $\underset{\infty}{m}$ & \& & $\stackrel{n}{n}$ & 옥 & $\underset{\infty}{\sim}$ & ৪্ল & $\tilde{\approx}$ & 오ํ \\
\hline & & ə「̣odeu ! əzכMAžods & $\stackrel{\text { ¿ }}{N}$ & $\stackrel{-}{\text { ㄱ. }}$ & 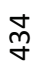 & ठ̊ & 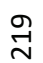 & $\begin{array}{l}\varphi \\
\overrightarrow{6}\end{array}$ & హ్ & 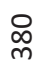 & 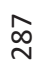 & ন্ণ \\
\hline & & 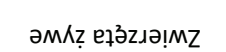 & -1 & $m$ & $m$ & N & -1 & 6 & $m$ & in & $m$ & $r$ \\
\hline \multicolumn{3}{|c|}{ 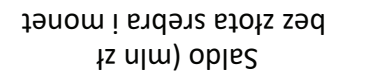 } & $\underset{\approx}{\approx}$ & 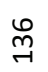 & 吕 & மำ & 용 & $\hat{n}$ & 芯 & $\stackrel{\infty}{\curvearrowright}$ & $\stackrel{\widehat{\infty}}{\rightarrow}$ & $\underset{子}{-}$ \\
\hline \multicolumn{3}{|c|}{ (łz upw) ł } & $\underset{\Im}{\Im}$ & 岮 & $\stackrel{\hat{A}}{N}$ & $\begin{array}{l}\infty \\
\stackrel{\infty}{\sim}\end{array}$ & 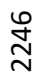 & $\stackrel{\stackrel{n}{\sim}}{\stackrel{n}{N}}$ & $\stackrel{\infty}{\stackrel{\leftrightarrow}{N}}$ & 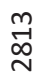 & $\stackrel{m}{\sim}$ & 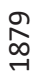 \\
\hline \multicolumn{3}{|c|}{ (łz u|u) д дodul } & 㭊 & 옴 & $\stackrel{\text { \& }}{\stackrel{\sim}{\sim}}$ & 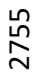 & مి & م్ & $\underset{\substack{m \\
m}}{m}$ & $\underset{m}{\stackrel{-}{-1}}$ & $\stackrel{\mathscr{L}}{\mathbb{N}}$ & $\begin{array}{l}\infty \\
\stackrel{\infty}{\circ} \\
\stackrel{\sim}{+}\end{array}$ \\
\hline \multicolumn{3}{|r|}{ yоy } & స్త & $\underset{\mathcal{N}}{\mathscr{N}}$ & ন্ন & ผุ & $\underset{\text { พั }}{\text { Oे }}$ & సิ & ๙ั & ฟิ & 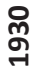 & ஜून \\
\hline
\end{tabular}




\begin{tabular}{|c|c|c|c|c|c|c|c|c|c|c|c|}
\hline \multicolumn{3}{|c|}{ 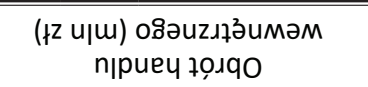 } & \multirow[b]{2}{*}{ กิ } & \multirow[b]{2}{*}{ 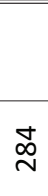 } & \multirow[b]{2}{*}{$\stackrel{\infty}{\sim}$} & \multirow[b]{2}{*}{$\stackrel{\infty}{\stackrel{0}{\sim}}$} & \multirow[b]{2}{*}{ ஜे } & \multirow[b]{2}{*}{$\begin{array}{l}\stackrel{\varphi}{m} \\
\vec{m}\end{array}$} & \multirow[b]{2}{*}{$\stackrel{\infty}{\lesssim}$} & & \multirow[t]{2}{*}{ 占 } \\
\hline \multirow{4}{*}{ 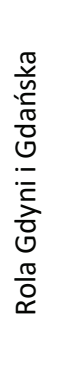 } & \multirow{2}{*}{ 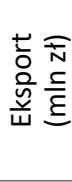 } & ysuepg & & & & & & & & & \\
\hline & & е!uイpg & $\overrightarrow{ }$ & 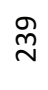 & $\stackrel{?}{\lesssim}$ & $\vec{m}$ & 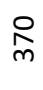 & 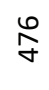 & $\stackrel{\stackrel{\infty}{\infty}}{\stackrel{\infty}{+}}$ & & नू \\
\hline & \multirow{2}{*}{ 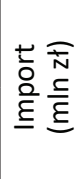 } & ysuepg & $\stackrel{\infty}{\stackrel{\infty}{-}}$ & $\underset{\sim}{\stackrel{\sim}{\sim}}$ & హా & 尺 & 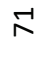 & $\underset{-}{8}$ & $\infty$ & & $\begin{array}{l}\stackrel{\bullet}{\infty} \\
\stackrel{\infty}{m}\end{array}$ \\
\hline & & е!u/pg & $\stackrel{m}{\rightarrow}$ & ลે & $\stackrel{\stackrel{\infty}{\infty}}{m}$ & भु & $\stackrel{\infty}{n}$ & $\stackrel{-}{N}$ & ๙̊ & & 茼 \\
\hline \multirow{10}{*}{ 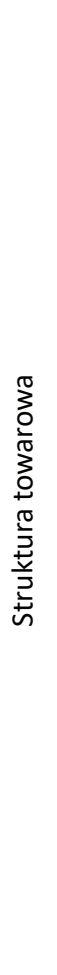 } & \multirow{5}{*}{ 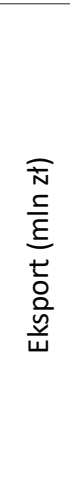 } & 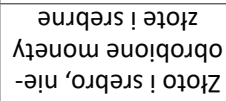 & $\stackrel{\mathbb{N}}{\sim}$ & $\infty$ & n & & & & & & $\sum_{m}^{\dot{n}}$ \\
\hline & & әмозов КqодКM & $\stackrel{+}{\sim}$ & $\stackrel{\infty}{N}$ & $\stackrel{\stackrel{n}{N}}{N}$ & & & & & & : \\
\hline & & 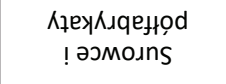 & ஜั & $\tilde{\sigma}$ & ச̊아 & & & & & & 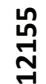 \\
\hline & & 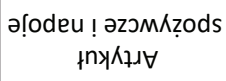 & $\stackrel{\stackrel{n}{m}}{m}$ & $\stackrel{\varphi}{\sim}$ & $\stackrel{n}{\sim}$ & & & & & & 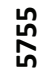 \\
\hline & & әмКํ еłるzıə!MZ & m & $\stackrel{\sim}{\sim}$ & $\stackrel{\infty}{\sim}$ & & & & & & $\underset{\text { N్}}{\stackrel{-}{-1}}$ \\
\hline & \multirow{5}{*}{ 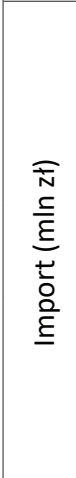 } & 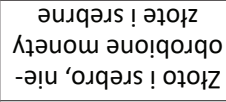 & 今 & ๓ั & กิ & & & & & & นั่ \\
\hline & & әмодов КqодКМ & $\tilde{W}$ & $\stackrel{ }{\stackrel{1}{m}}$ & రి & & & & & & $\underset{\mathbb{A}}{\stackrel{-}{Z}}$ \\
\hline & & 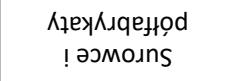 & $\stackrel{\varphi}{m}$ & 암 & $\stackrel{\Re}{\forall}$ & & & & & & స̃ \\
\hline & & 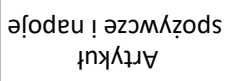 & $\stackrel{\mathscr{m}}{\rightarrow}$ & $\stackrel{\bullet}{\circ}$ & 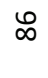 & & & & & & $\stackrel{m}{\mathcal{Z}}$ \\
\hline & & 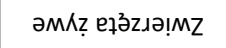 & -1 & -1 & -1 & & & & & & $\vec{z}$ \\
\hline \multicolumn{3}{|c|}{ 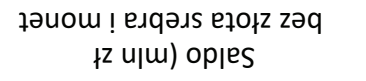 } & 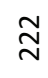 & $\stackrel{m}{\rightarrow}$ & 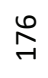 & రి & $\stackrel{m}{\sim}$ & ํํำ & $\stackrel{\text { n }}{\underset{7}{-}}$ & 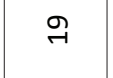 & \\
\hline \multicolumn{3}{|c|}{ (łz upu) Hodsy } & $\underset{\sim}{+}$ & ஜ & $\stackrel{n}{\frac{n}{n}}$ & $\stackrel{\text { }}{\text { N }}$ & 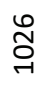 & 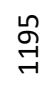 & 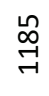 & $\stackrel{-1}{\infty}$ & 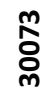 \\
\hline \multicolumn{3}{|c|}{ (łz uןw) łıodmן } & $\widetilde{్}$ & $\underset{\infty}{\lesssim}$ & ஓ & $\vec{\varnothing}$ & $\stackrel{m}{\circ}$ & $\stackrel{+}{\stackrel{+}{\sim}}$ & 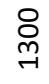 & ํำ & फे \\
\hline \multicolumn{3}{|r|}{ yoy } & ָू & $\underset{\mathscr{m}}{\stackrel{n}{\sigma}}$ & 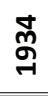 & $\stackrel{\text { ñ }}{\text { g }}$ & ֻัฒ & ભે & $\stackrel{\infty}{\stackrel{N}{్}}$ & 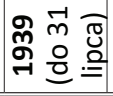 & 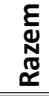 \\
\hline
\end{tabular}




\section{Stanisław Waltoś GRABIEŻ ołtarza Wita Stwosza}

Q1 wolters kluwer 